\title{
L'abocador ceràmic de finals del segle III dC de la vil·la romana dels Castellets (la Canonja, Tarragonès)
}

The pottery from the $3^{\text {rd }}$ century $A D$ refuse pit at the Roman villa of the Castellets (La Canonja, Tarragonès)

Les excavacions preventives realitzades entre els anys 2013 i 2014 dins el Parc Químic de Bayer Material Science, S. L. (la Canonja, Tarragona), van posar al descobert una magnífica vil.la romana amb diferents fases arquitectòniques i una cronologia que va del segle I al segle vII dC. Dins d'aquesta periodització, en aquest article exposem el resultat de l'anàlisi integral de l'abocador ceràmic evidenciat durant els treballs arqueològics, amb una datació de finals segle III dC, i vinculat probablement al període de les ràtzies franques.

Paraules clau: Tarraco, villa, abocador ceràmic, ceràmica romana, segle III dC.
The archaeological excavations undertaken between 2013 and 2014 at the Bayer Material Science Chemical Park (La Canonja, Tarragona) brought to light a magnificent Roman villa with different architectural and chronological phases ranging from the $1^{\text {st }}$ to $7^{\text {th }}$ century AD. This study presents the results of the study of the pottery uncovered in a refuse tip dating from the end of the $3^{\text {rd }}$ century probably linked to Frankish raids.

Keywords: Tarraco, villa, pottery, refuse tip, Roman pottery, $3^{\text {rd }}$ century AD. 


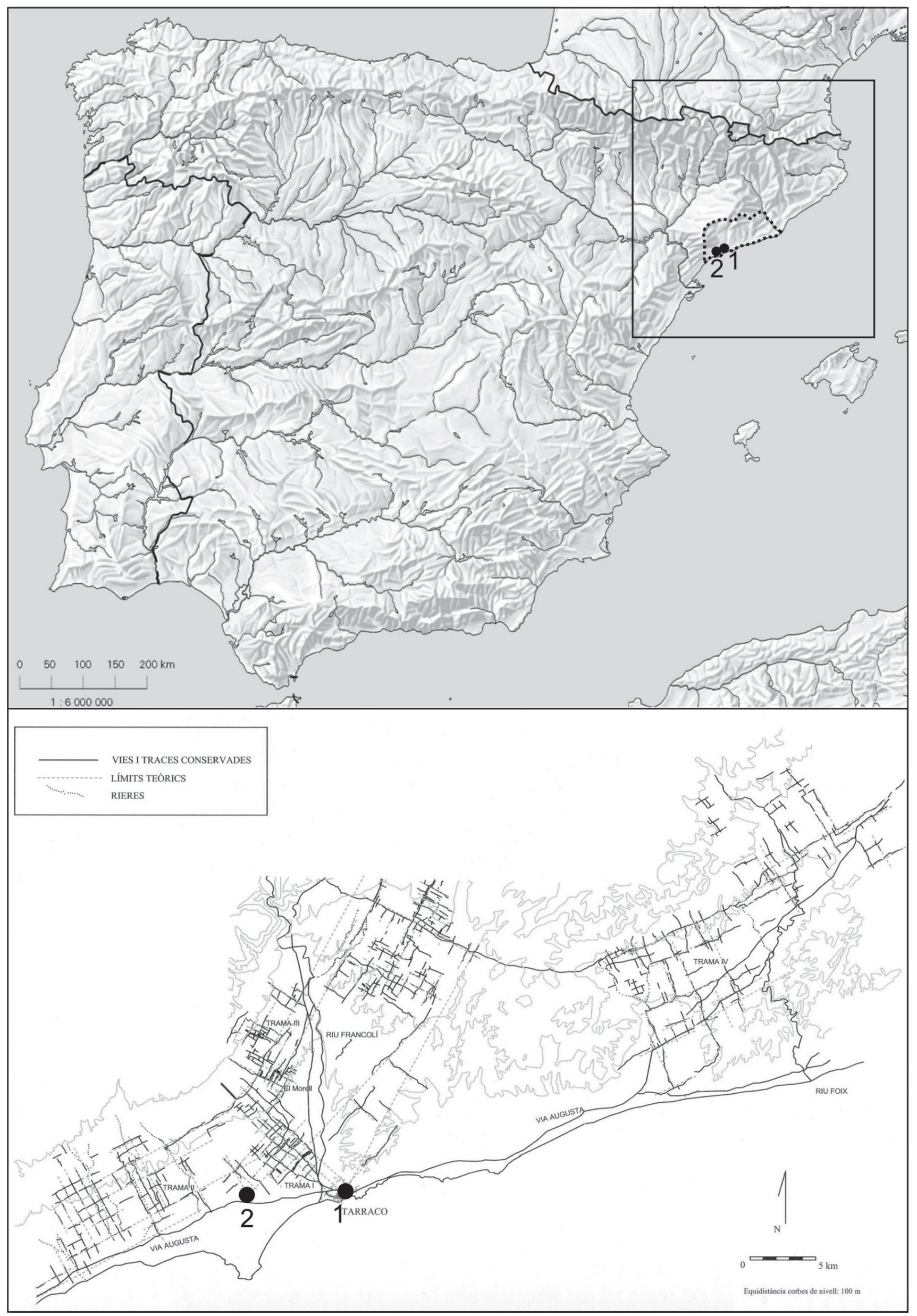

Figura 1. Superior: situació de Tarraco (punt número 1) i de la vil.la dels Castellets (punt número 2) dins dels límits de l'Ager Tarraconensis (en línia discontínua). Inferior: Tarraco (punt número 1) i villla dels Castellets (punt número 2) dins del tramat de les centuriacions de l'Ager Tarraconensis (plànol extret de Palet 2008). 


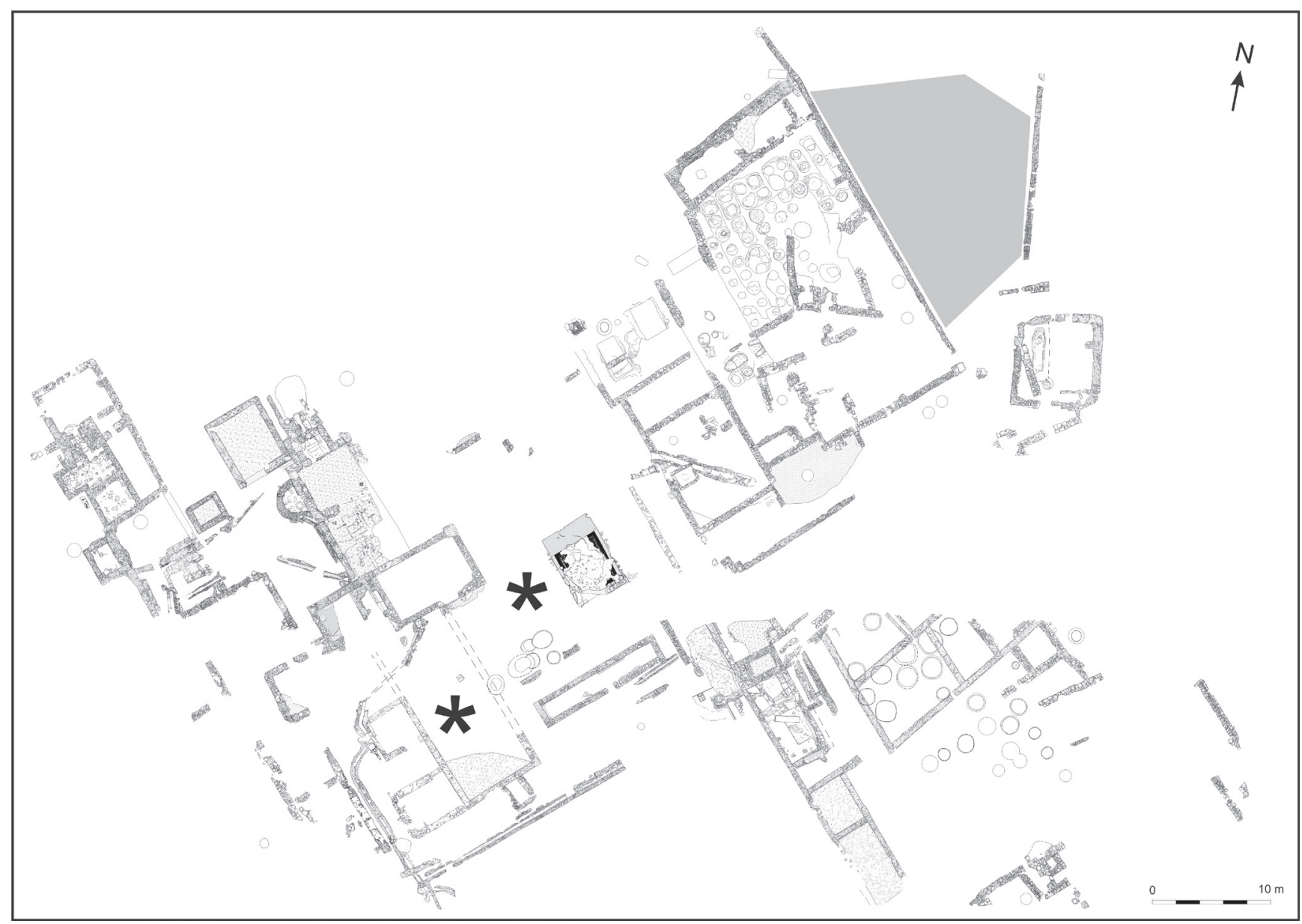

Figura 2. Planta general del jaciment amb la situació de l'abocador, en color gris, al costat superior dret de la imatge. La pars urbana de la vil.la del segle II dC és marcada amb un asterisc (autor Codex S.C.C.L.).

\section{Introducció}

El jaciment es troba a uns 10 quilòmetres del centre urbà de Tarragona, dins dels terrenys del Parc Químic de Bayer Material Science, S. L. a la Canonja, comarca del Tarragonès (figura 1). La intervenció arqueològica, executada per l'empresa CodexArqueologia i Patrimoni ${ }^{1}$ fou motivada per la construcció d'una nova planta (propietat de Kemira Ibérica, S. A.), destinada a la fabricació de productes per al tractament d'aigües (residuals i potables) i per a la indústria paperera.

Els treballs arqueològics van posar al descobert un assentament rural tipus vil.la litoral (amb una superfície entorn els $7.500 \mathrm{~m}^{2}$ ), amb unes característiques força coherents amb altres jaciments documentats al territorium de Tarraco però amb una àmplia ocupació, ja que es va poder identificar un volum de restes d'època romana amb una cronologia que va des del segle I dC fins a finals del segle viI dC (Roig et al. en premsa).

Les dades que exposem en aquest article són fruit de l'estudi ceràmic de l'abocador documentat a l'extrem nord del solar excavat (figura 2). La seqüència estratigràfica estava formada per tres nivells de terra, codificats amb les UE 2371, 4275 i 4436. L'excavació d'aquests estrats va permetre recuperar un volum de material arqueològic realment excepcional, 18.300 fragments. D'aquests en destaquem el format pel material ceràmic, amb un total de 15.368 peces. $^{2}$ La coherència cronològica de les classes i categories ceràmiques que componen aquest conjunt ens permet situar aquest abocament entorn de les darreries del segle III dC, amb posterioritat a un moment de destrucció de la pars urbana de la vil.la del segle II dC, causat molt probablement per la invasió franca (Roig et al. en premsa).

Val a dir que en aquest abocador també es recuperaren altres restes d'interès arqueològic, com ara fauna i malacologia terrestre i marina, plaques i motllures de marbre, fragments de pintura parietal, agulles d'os, vaixella de vidre i petits objectes de bronze. Unes peces que no exposarem en aquest treball, ja que no és la seva finalitat, perquè com ja hem dit més amunt, el que pretenem és donar a conèixer un
1. Els directors de les diverses intervencions foren Marc Gimeno Mariné, Josep Francesc Roig Pérez i Eduard Solà Agudo, amb la col-laboració de Paula Garcia-Medrano.
2. UE 2371: 12.982 fragments, UE 4275: 4.418 fragments i UE 4436: 900 fragments, tot i que aquest darrer destaca pel gran volum de fragments d'estucs: 702 . 
conjunt tancat de materials ceràmics procedents d'un abocador format en un moment cronològic concret. I és en això on resideix el seu principal interès, en l'homogeneïtat cronològica, alhora que ens permetrà conèixer també les diferents formes i tipologies ceràmiques d'ús quotidià més corrents i característiques d'una vil.la de l'ager Tarraconensis a les darreries del segle III dC.

Pel que fa a la representació gràfica de les peces ceràmiques, hem de dir que no s'ha prioritzat el dibuix de les més representatives, sinó d'aquelles que es trobaven més senceres i per tant en millor estat de conservació, un fet gens estrany per a aquest tipus de dipòsit si tenim present com es va produir la seva deposició.

\section{L'abocador}

Tal com ja hem apuntat, aquest abocador era compost per tres estrats, codificats amb les UE 2371, 4275 i 4436. La diferenciació numèrica entre els tres nivells respon únicament a qüestions metodològiques producte del procés d'excavació, ja que pel que fa a composició, coloració i textura, els tres estrats eren idèntics: coloració obscura (com a conseqüència de processos de descomposició de matèria orgànica), textura arenosa i composició a base de terres amb gran quantitat de cendres i carbons, material ceràmic de tot tipus, objectes de vidre, elements de marbre, utensilis metàl-lics i d'os, restes de fauna i també de malacologia, tant terrestre com marina.

La superfície superior del conjunt es trobava notablement horitzontalitzada, fruit dels processos agrícoles i urbanístics duts a terme en aquesta zona fins poc abans de la nostra intervenció. L'excavació del conjunt (amb una superfície de planta irregular, entorn dels $300 \mathrm{~m}^{2}$ i una potència entre els $0,30 \mathrm{i}$ els 1,50 metres segons la profunditat del substrat natural) va permetre comprovar que l'abocament es va produir en sentit oest-est, és a dir, de l'interior de la vil.la vers l'exterior, alhora que també s'identificaren diferents capes de llims molt fines, fet que ens evidenciaria una deposició antròpica, espaiada en el temps però alhora continuada, tal com es desprèn de l'estudi del material arqueològic associat. Sota el paquet de terres es documentà el substrat geològic corresponent al sòl neogen característic del Camp de Tarragona, compost d'argila rogenca i gravetes carbonatades, així com materials silicis propis d'un ambient marcadament humit.

Abans de continuar, volem fer un incís i parlar del material residual. Es tracta d'un conjunt format per 57 fragments, ${ }^{3}$ la presència dels quals respon al fet que foren llençats a l'interior de l'abocador en

3. 1 informe i 1 carena de comuna oxidada ibèrica; 2 informes, 1 vora de López 54, 4 vores de Mayet 40 i 1 vora indeterminada de parets fines; 1 aleta de Lamb. 36 en Campaniana A; 1 carena, 1 fons, 6 informes i 1 vora de gerreta de comuna itàlica; 1 informe i 7 fons de roig intern pompeià; 1 carena de vernís negre indeterminat; 2 vores d'àmfora ibèrica; 1 vora de Haltern 70; 1 fons de TS Marmoratta; 1 vora i 4 anses de Dr. 2 d'àmfora itàlica; 7 anses i 6 vores de Dr. 2 d'àmfora tarraconense; 3 becs, 2 orles i 1 ansa de llàntia de disc.

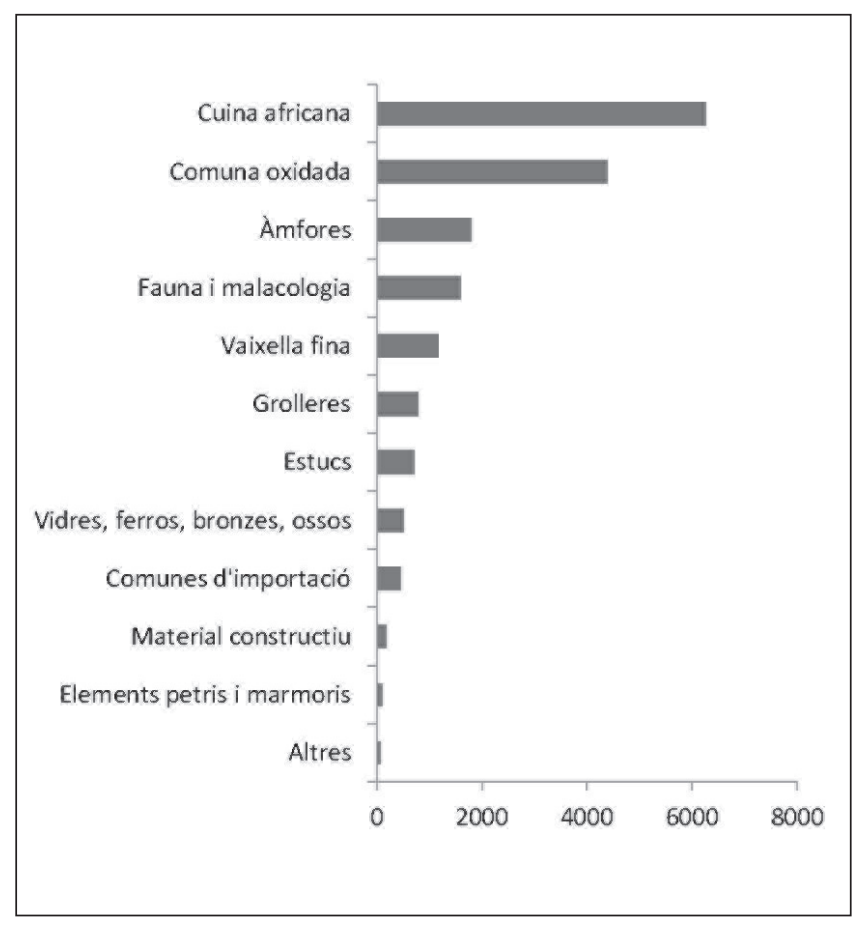

Figura 3. Quadre amb els diferents tipus de material arqueològic recuperat, i amb el seu percentatge.

el moment que aquest es va formar, tot barrejant els materials que componen l'abocador amb d'altres procedents de nivells precedents. La seva identificació ens permet confirmar l'existència d'un assentament anterior a la construcció de la gran vil-la del segle II dC.

\section{Materials i cronologia}

El material arqueològic d'aquest abocador el componen diferents classes d'objectes; a partir del nombre de peces recuperades, les hem ordenat de més a menys (figura 3).

S'observa un predomini absolut de les produccions africanes, tant pel que fa a la vaixella fina com a la ceràmica de cuina africana. Un domini que queda confirmat també per les imitacions locals de formes africanes, i que analitzarem més endavant. En segon lloc, i a gran distància del tercer grup tipològic -les àmfores-, cal valorar la magnitud que conforma el conjunt de les comunes oxidades. A continuació, i per sota de la fauna i la malacologia, les quantitats dels diferents tipus ceràmics es redueixen força. Si entrem en el detall, hem de dir que el $35 \%$ de la totalitat del conjunt es compon de ceràmica de cuina africana, en segon lloc la comuna oxidada amb el $24 \%$, les àmfores ocupen el tercer lloc amb un percentatge del $10 \%$. En quart lloc, i amb un $9 \%$, la fauna i malacologia, i a continuació, de major a menor, la vaixella fina amb un $6 \%$, les grolleres i els estucs, ambdós amb un $4 \%$. El conjunt format pels vidres, metalls, ossos treballats i monedes representen el $3 \%$ igual que les comunes d'importació (amb l'excepció de les africanes). I finalment el material constructiu i els elements petris i marmoris amb un $1 \%$ cadascun. 


\section{La vaixella fina}

Aquesta categoria és formada per TS Africana A, TS Africana A/D, TS Africana C, TS Hispànica, TS Hispànica Tardana, ceràmica coríntia, vidriada romana i llànties (figures 4, 5, 6 i 7).

De tot el conjunt, la classe ceràmica més representada és la TS Africana A amb 1.934 fragments (71,5\% del total de la vaixella fina) i 410 NMI, en segon lloc les TS Africana C amb un total de 294 fragments $(13,7 \%)$ i 75 NMI, en tercer lloc les TS Hispàniques amb 70 informes (5\%) i 26 NMI, en quart lloc les TS Hispàniques Tardanes amb 42 fragments $(3,7 \%)$ i 6 NMI, en cinquè lloc les TS Africana $\mathrm{A} / \mathrm{D}$ amb un total d'11 fragments $(0,3 \%)$ i 10 NMI. I en darrer lloc, voldríem fer esment del conjunt ceràmic format per les ceràmiques corínties amb 14 fragments $(1,1 \%)$ i 7 NMI, les vidriades romanes amb 2 vores, 4 llànties de disc tipus Dr. 20, 1 llàntia de canal tipus Dr. 5C i una altra de volutes tipus Dr. 10 (la totalitat de fragments corresponents a llànties correspon al 3,7\%).

Tal com acabem de dir, la TS Africana A es troba en el primer lloc tant pel que fa a la quantitat com a la diversitat tipològica. I en l'àmbit cronològic, cal destacar que es recuperaren formes més pròpies de la primera etapa de producció: Lamb. 1c/Hayes 8B, Lamb. 2a/Hayes 9A, Lamb. 2b/ Hayes 9B, Lamb. 4/36A/ Hayes 3B, Lamb. 4/36B/Hayes 3C, Lamb. 19/Hayes 22, Lamb. 23/Hayes 6B (finals segle I dC - mitjan segle II $\mathrm{dC})$, i també d'altres plenament tardanes: Lamb. 3a/ Hayes 14A, Lamb. 3b ${ }^{1} /$ Hayes 14B, Lamb. 3b $/$ Hayes 14C, Lamb. 3c1/Hayes 16, Lamb. 8/Hayes 17A, Lamb.

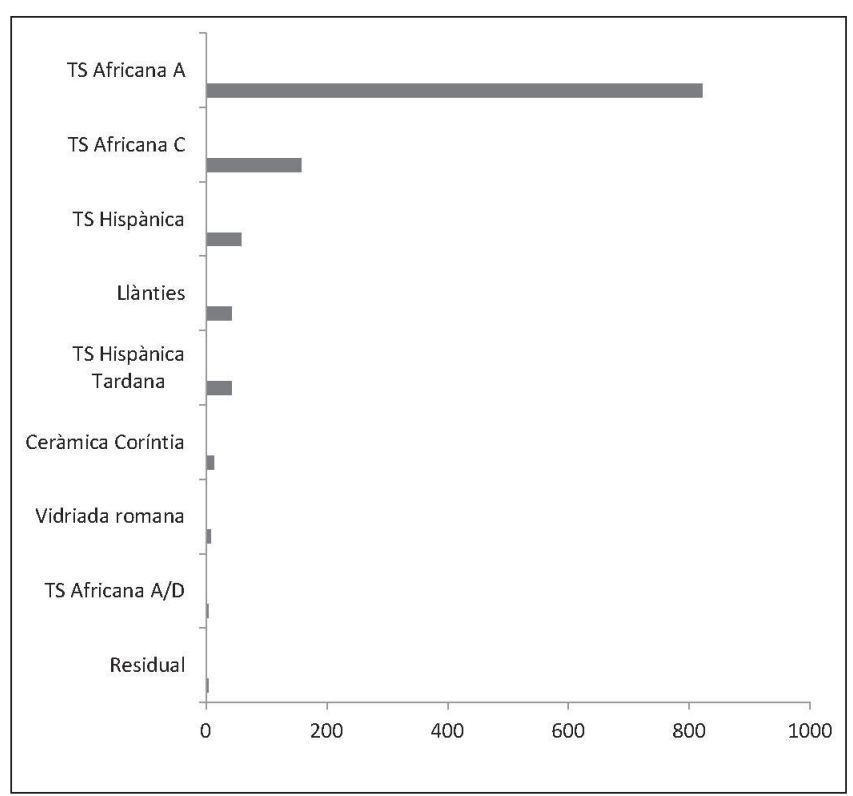

Figura 4. Quadre amb el percentatge de fragments recuperats de TS Africana A, TS Africana A/D, TS Africana C, TS Hispànica, TS Hispànica Tardana, ceràmica Coríntia, vidriada romana i llànties.

9a i $9 \mathrm{a}^{2} /$ Hayes 27, Lamb. 9b/Hayes 26, Hayes 31 i Ostia I, 57 (segona meitat segle II dC - segle III dC).

Si bé queda reflectit el domini de les copes Lamb. $3 b^{2} /$ Hayes $14 \mathrm{C}$, Lamb. 3c ${ }^{1} /$ Hayes 16 , Lamb. 3/8/Hayes 17A i els plats Lamb. 9b/Hayes 26 i Hayes 31, les dues formes més representades són les copes Lamb. 3b $b^{1 / H a y e s ~ 14 B ~ i ~ L a m b . ~ 8 / H a y e s ~ 17 A, ~ a m b ~} 65$ individus

\begin{tabular}{|c|c|c|}
\hline Classe ceràmica & Tipus & NMII \\
\hline \multirow[t]{18}{*}{ TS Africana A } & Lamb. 1c/Hayes $8 \mathrm{~B}$ & 7 \\
\hline & Lamb. 2a/Hayes 9A & 11 \\
\hline & Lamb. 2b/Hayes 9B & 2 \\
\hline & Lamb. 3a/Hayes 14A & 4 \\
\hline & Lamb. $3 \mathrm{~b}^{1} /$ Hayes $14 \mathrm{~B}$ & 65 \\
\hline & Lamb. $3 b^{2} /$ Hayes $14 \mathrm{C}$ & 30 \\
\hline & Lamb. 3c1/Hayes 16 & 23 \\
\hline & Lamb. 3/8/Hayes 17A & 23 \\
\hline & Lamb. 4/36A/Hayes 3B & 3 \\
\hline & Lamb. 4/36B/Hayes 3C & 9 \\
\hline & Lamb. 8/Hayes 17A & 70 \\
\hline & Lamb. 9a/Hayes 27 & 7 \\
\hline & Lamb. $9 \mathrm{a}^{2} /$ Hayes 27 & 11 \\
\hline & Lamb. 9b/Hayes 26 & 45 \\
\hline & Lamb. 19/Hayes 22 & 2 \\
\hline & Lamb. 21/Hayes 10 & 1 \\
\hline & Lamb. 23/Hayes 6B & 5 \\
\hline & Hayes 31 & 30 \\
\hline
\end{tabular}

\begin{tabular}{|c|c|c|}
\hline & Ostia I, 57 & 4 \\
\hline \multirow[t]{4}{*}{ TS Africana A/D } & Hayes 32 & 1 \\
\hline & Hayes 33 & 1 \\
\hline & Símil Hayes 32-33 & 1 \\
\hline & $? ?$ & 1 \\
\hline \multirow[t]{8}{*}{ TS Africana $\mathrm{C}$} & Hayes 42 & 1 \\
\hline & Hayes 44/Lamb. 35 & 6 \\
\hline & Hayes 45 & 4 \\
\hline & Hayes 45A/Lamb. 42 & 3 \\
\hline & Hayes 48A/Lamb. 41 & 1 \\
\hline & Hayes 49 & 1 \\
\hline & Hayes 50 & 6 \\
\hline & Hayes 50A/Lamb. 40 bis & 31 \\
\hline \multirow[t]{6}{*}{ TS Hispànica } & Drag. $15 / 17$ & 13 \\
\hline & Drag. 18 & 1 \\
\hline & Drag. 19? & 1 \\
\hline & Drag. 27 & 5 \\
\hline & Drag. 29 & 1 \\
\hline & Drag. 30 & 1 \\
\hline
\end{tabular}

\begin{tabular}{|l|l|l|}
\hline & Drag. 37a & 7 \\
\hline & Mezq. 1? & 1 \\
\hline & Ritt. 8 & 2 \\
\hline TS Hisp. Tardana & Símil Mezq. 77 & 1 \\
\hline & Ritt. 8 & 1 \\
\hline & Drag. 27 & 1 \\
\hline Ceràmica Corintia & Spit. 1942, fig. I-22 & 11 \\
\hline Vidriada Romana & Desbat 1986G, fig. 2.9 & 2 \\
\hline Llàntia de Canal & Dr. 5C & 2 \\
\hline Llàntia de Disc & Dr. 20 & 1 \\
\hline Llàntia de Volutes & Dr. 10 & 2 \\
\hline
\end{tabular}

Figura 5. Quadre amb les diferents formes identificades de TS Africana A, TS Africana A/D, TS Africana C, TS Hispànica, TS Hispànica Tardana, ceràmica Coríntia, vidriada romana i llànties. 


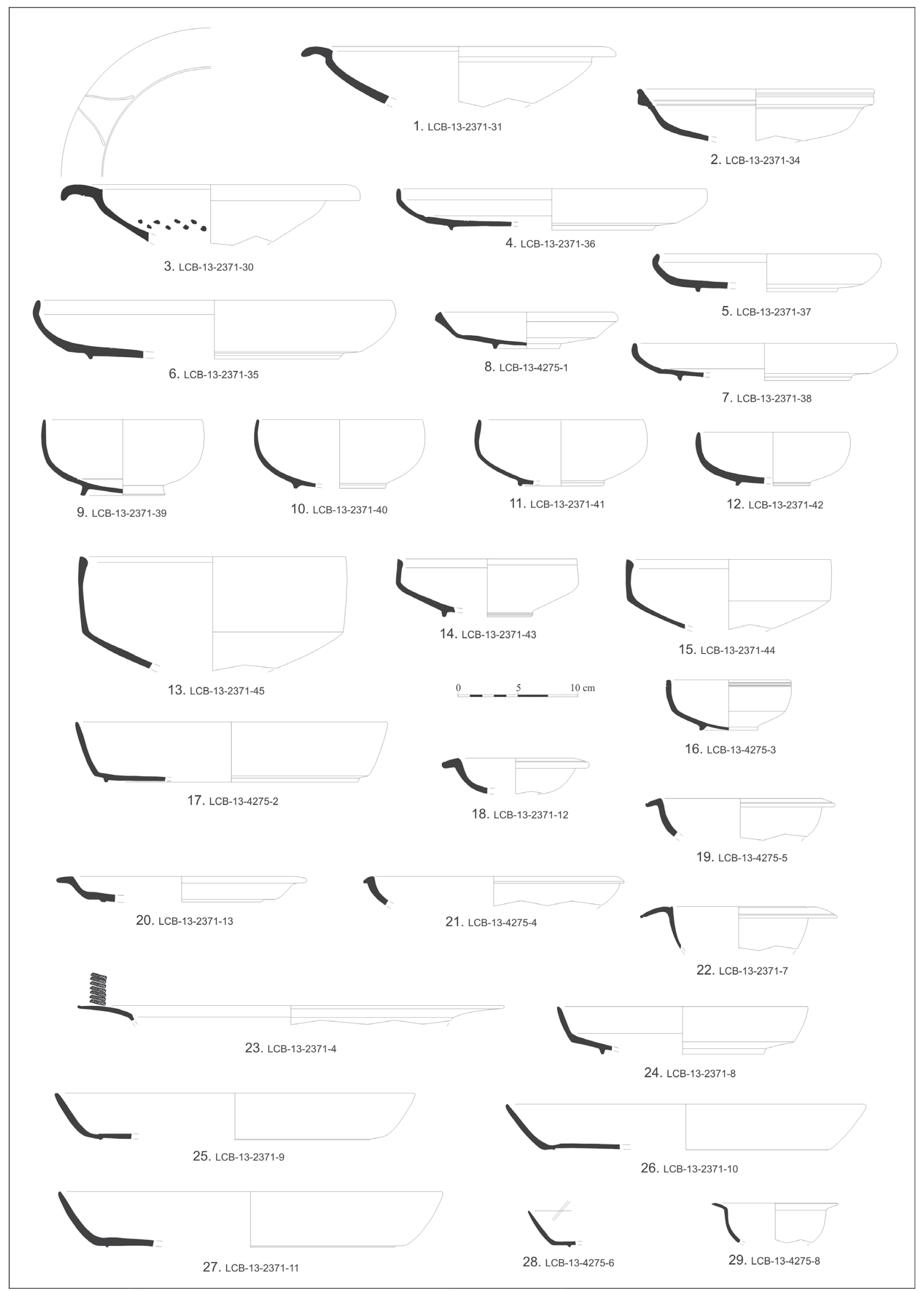

Figura 6. TS Africana A: 1. Lamb. 4/36B/Hayes 3C; 2. Lamb. 1C/Hayes 8B; 3. Hayes 3B-C; 4 i 6. Lamb. 9B/Hayes $26 ; 5$. Lamb. 9A/Hayes 27; 7. Lamb. 9A ${ }^{2} /$ Hayes 27; 8. Lamb. 3C $1 /$ Hayes 16; 9 , 10 i 11. Lamb. 8/Hayes 17A; 12. Ostia I, fig. 57; 13 i 15. Lamb. 3B $1 /$ Hayes 14B; 14. Lamb. 3B $2 /$ Hayes 14C; 16. Lamb. 3/8/Hayes 17A; 17. Hayes 31. TS Africana A/D: 18. Hayes 32; 19. Símil Hayes 32-33; 20. Hayes 33; 21. forma indeterminada. TS Africana C: 22 i 29. Hayes 44/Lamb. 35; 23. Hayes 45A/ Lamb. 42; 24-28. Hayes 50A. 


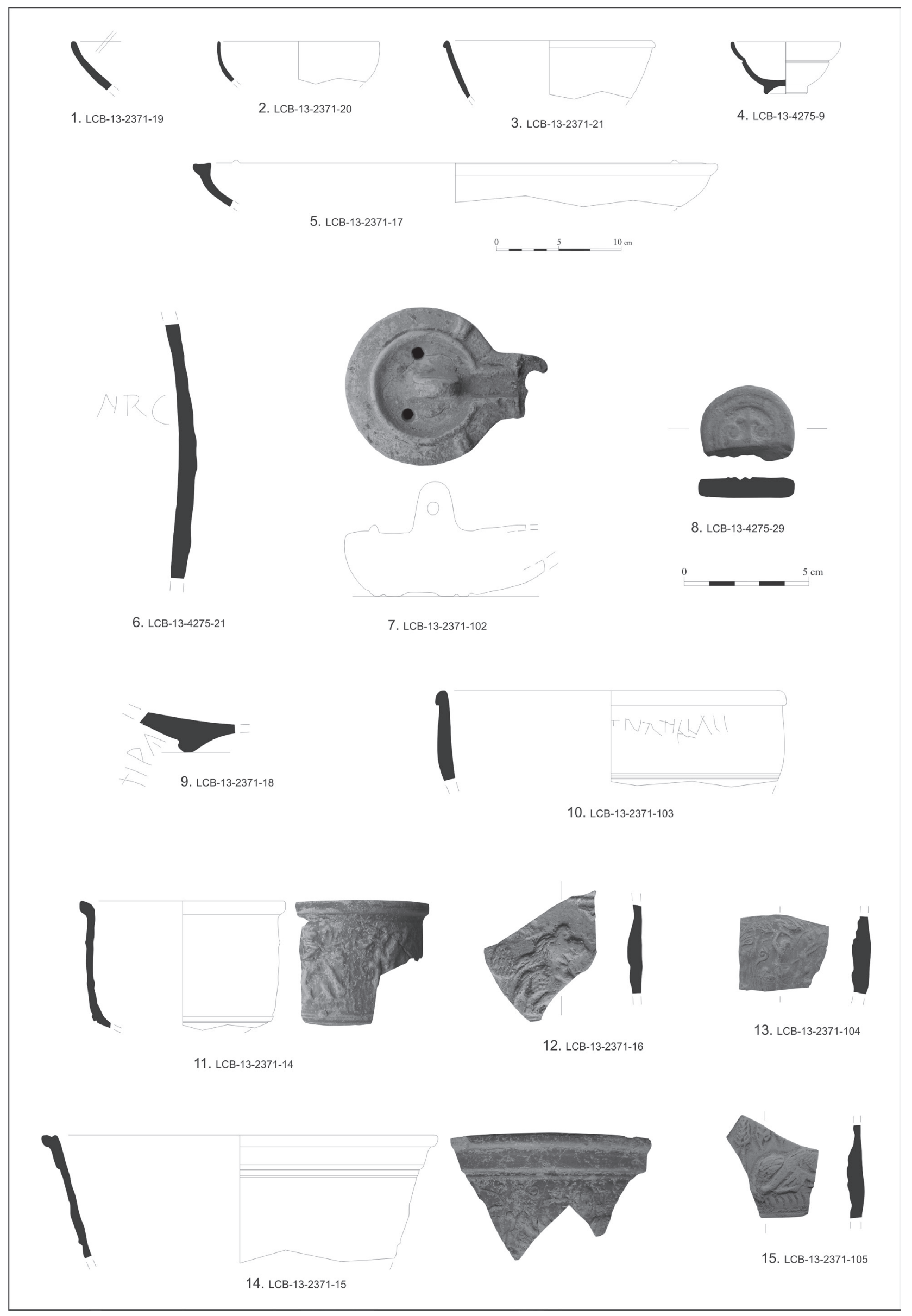

Figura 7. TS Hispànica tardana: 1. Símil. Mezq. 77; 2. Ritt. 8; 3. Símil Drag. 37b; 4. Drag. 27; 10. Drag. 73a amb grafit post cocturam TNAHLVA(VA lligades)V. Vidriada romana: 5. Desbat 1986G, fig. 2.9. Comuna oxidada: 6. Grafit post cocturam ....NRC; 8. agafador amb motiu vegetal en relleu. Llàntia de canal: 7 . Dr. $5 \mathrm{C}$ amb ansa al disc. TS Hispànica: 9 . segell .... TIPA.... Ceràmica coríntia: 11-12. Spit. 1942, 170.1. 
per a la primera i 70 per a la segona. Entre ambdues representen el $38 \%$ de la totalitat de recipients de producció TS Africana A.

De la producció A/D tan sols es recuperen 4 vores corresponents als plats Hayes 32, Hayes 33, símil a Hayes 32-33 i una quarta de difícil adscripció. Unes formes molt comunes a aquesta producció típica del segle III dC (Atlante 1981: 52-53).

En relació amb les TS Africanes C la forma més representada correspon a l'escudella Hayes 50A/Lamb. 40 bis, més de la meitat $(58 \%)$ del total d'aquesta producció. La resta de formes recuperades són els plats Hayes 48A i Hayes 49, les escudelles Hayes 42, 45A i Hayes 50, i la copa Hayes 44.

Pel que fa a la cronologia, la forma Hayes 50A/ Lamb. 40 bis, se n'ha identificat de producció $\mathrm{C}^{1}$

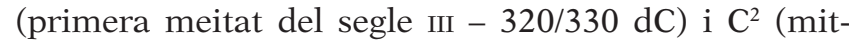
jan segle III - inicis segle IV dC) (Atlante 1981: 65; Hayes 1972: 73, 289-290). Val a dir que per a Atlante, aquesta diferència entre la $\mathrm{C}^{1} \mathrm{i}$ la $\mathrm{C}^{2}$ respon més a qüestions tècniques de producció i que la diferència cronològica entre les dues produccions seria menor a una generació (Atlante 1981: 58). Pel que fa als 6 exemplars de Hayes 50, una forma segons Atlante de transició entre la Lamb. 40 i la Hayes 50B, i de cronologia força imprecisa, es proposa una datació de primera meitat segle IV dC (Atlante 1981: 65). Per a la Hayes 44/Lamb. 35, es proposa una datació de 220/40 - finals segle III dC (Atlante 1981: 70) o una mica més enllà (Hayes 1972: 62). La Hayes 42, entre el $220 \mathrm{i}$ el 240/50 (Atlante 1981: 63). La Hayes 49, del 230/40 al $300 \mathrm{dC}$ circa (Atlante 1981: 61). I per a la Hayes 48A/Lamb. 41, entre el 220 i el 270 dC (Atlante 1981: 61; Hayes 1972: 67).

Aquesta producció constitueix un autèntic fòssil director per poder datar el moment que es va crear l'abocador, ja que tenim una datació post quem al voltant del $220 \mathrm{dC}$, facilitada per la producció $\mathrm{C}^{1}$, i també una datació ante quem, la dècada final del segle III $\mathrm{dC}$, tal com ens indiquen les 6 vores d'escudella de la forma Hayes 50, a més de la no identificació de cap fragment de la producció TS Africana D. I que segons Atlante, les formes més antigues corresponen a les escudelles Hayes 32/58 i Hayes 58B, amb una datació inicial de 290/300 dC (Atlante 1981: 81-82). Val a dir que per a Hayes aquesta datació s'ha d'avançar fins al 320-325 dC (Hayes 1972: 291-292).

Tot i que és una producció més pròpia de contextos més antics, també hem volgut incloure en aquest estudi les TS Hispàniques, unes ceràmiques que es fabriquen de manera generalitzada a partir de mitjan segle I dC seguint models de vaixella fina TS Itàlica i Sud-Gàl-lica, i que en comptades excepcions poden arribar fins al segle III dC, com serien la copa Drag. 27 i el plat Drag. 15/17 (Romero, Ruiz 2005: 189). De l'abocador es recuperen plats (formes Drag. 15/17, Drag. 18 i una possible Drag. 19), copes (forma Drag. 27 i Ritt. 8), bols (formes Drag. 29, Drag. 30 i Drag. 37a) i una vora de possible gerreta (Mezq. 1).

La producció que substitueix l'anterior, és la TS Hispànica Tardana, també representada en l'abocador de la vil.la dels Castellets, tot i que en un nombre molt inferior respecte a les seves predecessores (16\% contra el $84 \%$ del total de la producció hispànica).
Es tracta d'un tipus de ceràmica amb un vernís de menor qualitat i que fou fabricada en diferents tallers, fet que no ens permet identificar-ne l'origen. Tot i així, podem pensar en una procedència de la vall mitjana de l'Ebre o la mateixa Rioja, si tenim present el gran pes que va tenir aquesta zona en cronologies anteriors (Paz Peralta 2008: 497-498). D’aquesta producció en recuperarem les següents formes: Drag. 27, Drag. 37a, Ritt. 8, símil Drag. 37b i símil Mezq. 77. Segons la classificació tipològica de J. A. Paz Peralta aquests recipients corresponen als tipus cuenco 5.1, cuenco 4.24, escudilla 6.1, cuenco 4 i plato 8.1, respectivament, i són típics del que ell denomina época intermedia, amb una cronologia de circa 250-circa 330 dC (Paz Peralta 2008: 502-506, 512-516).

La ceràmica coríntia, tal com indica el seu nom va ser fabricada a Corint, i exportada a Hispania - així com a altres punts de l'imperi- entre mitjan segle II i la segona meitat del segle III dC. Formalment parlant hi ha un sol tipus, conegut com a Spitzer 1942, fig. I-22. (Spitzer 1942: 162-192; Malfitana 2000: 181-188). Tot i que es tracta d'una producció força minsa en comparació amb altres tipus ceràmics, se n'han trobat en força jaciments, sobretot a la costa oriental de la península Ibèrica (Casas, Merino 1990: 139-155; Granados 1979: 203-219).

Un altre tipus de producció identificada, però més reduïda en nombre que les ceràmiques corínties és la ceràmica vidriada. Un tipus de recipient que arriba a Hispania en època augustal i abraçant tot el període altimperial (Paz Peralta 2008: 489). Les zones de producció són la Gàl-lia, la Bètica, la regió oriental del Mediterrani i el Laci, actual Itàlia, d'on vindria l'exemplar recuperat a l'abocador de la vil.la dels Castellets, ja que es caracteritza per una pasta de bona qualitat i esmalt per ambdues cares, verd per fora i groc per dins (Sannazaro 2005: 425). El tipus recuperat correspon a una copa forma Desbat 1986, 2.9 amb una cronologia d'inicis del segle II i III dC (Desbat 1986: 33-39, fig. 2.9).

I en darrer lloc, les llànties, concretament una de canal tipus Dr. 5C, una altra de volutes tipus Dr. 10 i dues de disc tipus Dr. 20. Amb l'excepció de la llàntia de volutes Dr. 10 totalment residual (de Neró a inici de la dinastia flàvia), les tres llànties restants, tot i no tenir una cronologia gaire precisa, sí que podem dir que són força comunes en contextos del segle II dC (sobretot pel que fa a la Dr. 20), tot arribant en moments avançats del segle III dC (Celis 2005: 425 i 429). La llàntia Dr. 5C destaca també per un altre motiu, presenta una ansa al disc, un fet gens comú en aquest tipus de peces (figura 6,7 ).

\section{La cuina africana}

Es tracta d'un tipus de producció provinent de l'Africa Proconsularis, molt heterogènia, amb pastes ataronjades, arenoses, poroses i amb diversos acabats: vora fumada, polit a bandes o pàtina cendrosa, independent de la zona concreta de producció (Aquilué 1995: 61). Respecte a la seva cronologia, comença a exportar-se des d'època d'August, i a partir d'aquest moment, esdevé present en qualsevol jaciment amb 


\begin{tabular}{|c|c|c|}
\hline Classe ceràmica & Tipus & NMI \\
\hline \multirow[t]{22}{*}{ Cuina africana } & Atl. CVIII, 1 & 46 \\
\hline & Atl. CVIII, 2 & 2 \\
\hline & Caesaraugusta G/S 200 & 25 \\
\hline & Hayes 131 & 27 \\
\hline & Hayes 200 & 38 \\
\hline & Lamb. 9A/Hayes 181 & 111 \\
\hline & Lamb. 10A/Hayes 23B & 50 \\
\hline & Lamb. 10B/Hayes 23A & 189 \\
\hline & Ostia, I, 20/Hayes 185 & 12 \\
\hline & Ostia I, 56? & 1 \\
\hline & Ostia I, 261 & 716 \\
\hline & Ostia, I, 262/Hayes 195 & 58 \\
\hline & Ostia I, 264B & 2 \\
\hline & Ostia I, 270 & 7 \\
\hline & Ostia I, 272 & 8 \\
\hline & Ostia I, 273/Hayes 193 & 117 \\
\hline & Ostia I, 278 & 6 \\
\hline & Ostia II, 302 & 14 \\
\hline & Ostia III, 108 & 21 \\
\hline & Ostia III, 332/Hayes 196 & 241 \\
\hline & Ostia III, 267A/Hayes 197 & 144 \\
\hline & Ostia III, 267B/Hayes 197 & 500 \\
\hline
\end{tabular}

Figura 8. Quadre amb les formes identificades de cuina africana.

una datació fins ben entrat el segle vII dC. De fet, a Tarraco durant el primer quart del segle II dC la producció africana representa el 33,28\% de les comunes i de les cuines, mentre que durant el segle III dC és del 38,45\% (Aquilué 1992b: 26-27).

De l'abocador excavat, aquest és el tipus ceràmic més nombrós, tant pel que fa al nombre de fragments (6.257) com al d'individus (2.314). Val a dir també que s'ha identificat gairebé la totalitat del conjunt de formes produïdes en aquest tipus de producció, amb una cronologia global de segles I-III dC (figures 8 i 9). A més, per a aquest moment cronològic, i sempre segons Atlante, també aquelles formes més típiques del segle III dC, com són el plat tapadora Ostia I, 261, la cassola alta Ostia III, 267/Hayes 197, la marmita Ostia I, 56 i les cassoles baixes Lamb. 9A/ Hayes 181, Lamb 10A/Hayes 23B i en menor mesura Lamb. 10B/Hayes 23A (Atlante 1981, 211, 223). Val a dir que aquest conjunt de formes, amb l'excepció de l'Ostia I, 56, es manté encara en contextos del segle IV i possiblement també a inicis del v dC (Macias 1999: 85). De fet, el volum d'aquest tipus de producció és encara força gran en aquestes datacions, com ja va posar en evidència el context ceràmic del carrer d'Apodaca datat durant la primera meitat del segle IV dC i on s'identificà un $54,3 \%$ de ceràmica de cuina africana en relació amb la totalitat de la vaixella comuna (Macias 1999: 85).

Altres formes documentades també en contextos del segle III dC són el plat tapadora Ostia III, 332/ Hayes 196 (forma que es manté fins i tot en nivells del segle $\mathrm{v} \mathrm{dC}$, però ja de manera residual, Aquilué 1995: 67). Un altre plat tapadora, l'Ostia I, 264B, que apareix durant el segle II dC, és present també en contextos del segle III (Aguarod 1991: 256). De la mateixa manera passa amb l'olla Hayes 200 i amb la cassola Ostia III, 108, la primera present de finals del segle II fins a mitjan segle III dC (Hayes 1972: 211) i la segona, ${ }^{4}$ en contextos de la primera meitat del segle III dC (Aquilué 1992a i 1995: 69; Serrano 2005: 266-267).

Per contra, volem destacar també l'absència de les cassoles Raqqada 1973, XXX, B 24 així com les tapadores Ostia IV, 60 i Ostia IV, 61, amb una datació inicial entorn del $320 \mathrm{dC}$ (Atlante 1981: 212, 223-224; Aquilué 1992b; Macias et al. 1997: 164-165). Val a dir que aquesta darrera tapadora també ha estat documentada en un context de finals del segle III - inicis del Iv dC (Cerdà et al. 1998: 67).

Si bé queda reflectit el domini de les cassoles altes i dels plats tapadora, les dues formes més representades són el plat tapadora Ostia I, 261 i la cassola alta Ostia III, 267B/Hayes 197, segurament ambdues peces formarien part del mateix servei.

\section{La ceràmica comuna}

Aquesta categoria ceràmica és de gran interès, ja que ens permetrà conèixer la ceràmica comuna (de taula i de cuina) d'aquest moment concret. El gran nombre de perfils complets o restituïbles ens ha facilitat reconèixer un repertori tipològic molt heterogeni, amb ampolles, bols, cassoles, gerretes, gibrells, morters, olles de cocció, olles d'emmagatzematge, tapadores, tasses i urnes (figura 10). Val a dir que en aquest article s'exposen les millor conservades (figura 11).

El grau de depuració de les pastes és molt variable, amb abundants partícules de desgreixant de gra fi i petit de tipus micaci, quarcític i calcari, unes característiques que fan pensar en una producció dins de l'ager de Tarraco (Járrega i Buffat 2012: 453 i 466). Les peces són fetes a torn i no presenten cap tipus de tractament destacat a la superfície, amb alguna excepció on hem identificat engalba vermella, groga o taronja ${ }^{5}$ (figura 12, 5). Tot i que la majoria de la ceràmica comuna és de cocció oxidant, també n'hi ha de reduïda, en aquest cas concret, dues gerretes.

4. Per a Atlante aquesta forma es situa en contextos del 320-360 dC i del 360-440 dC (Atlante 1981, 219).

5. 15 informes, 2 fons, 1 coll i 3 carenes amb engalba vermella per la cara exterior. 2 fons d'engalba groga per la cara exterior i vermella per l'interior. 1 escudella amb engalba taronja per les dues cares. 


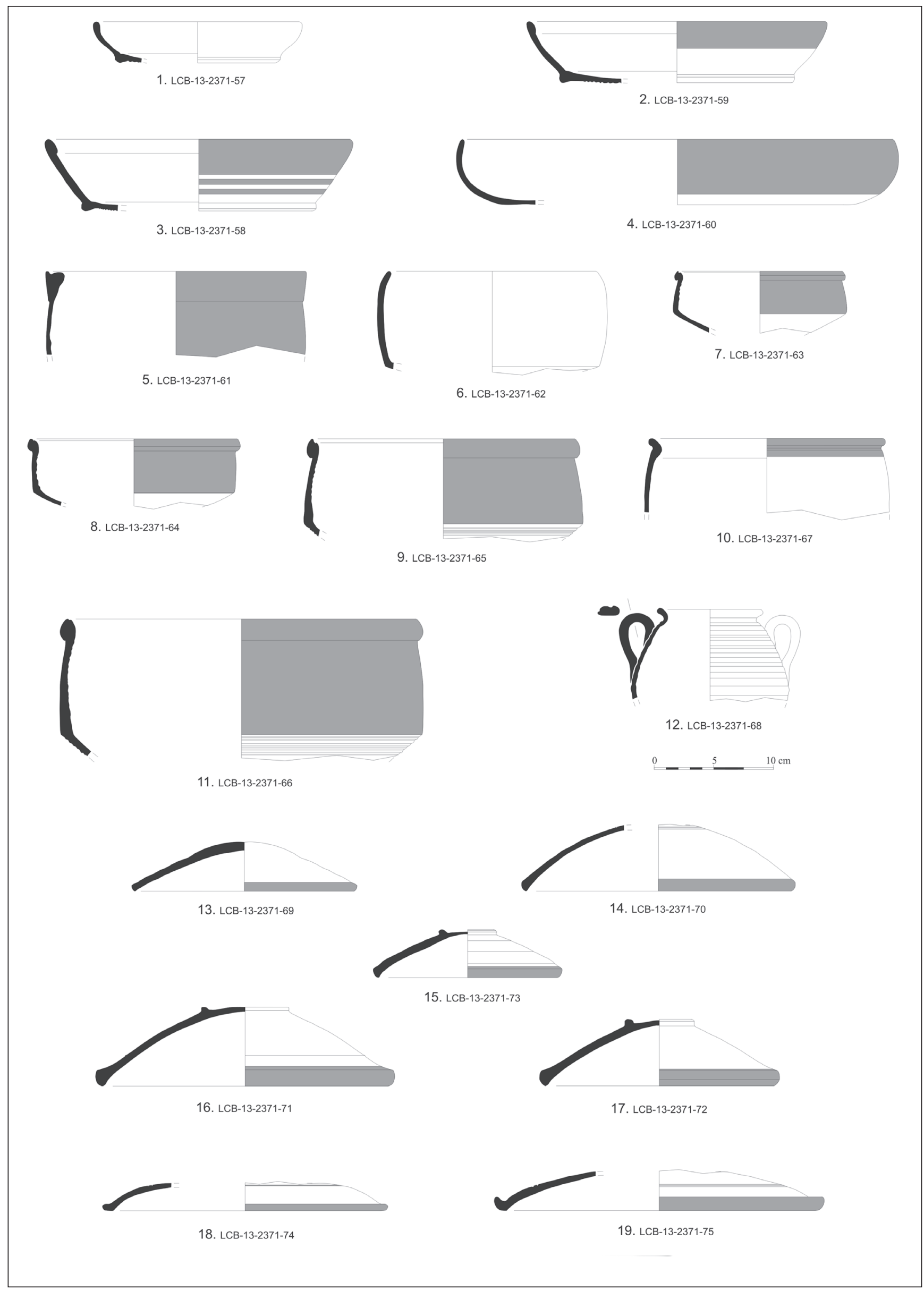

Figura 9. Cuina africana: 1. Lamb. 10B/Hayes 23A; 2 i 3. Lamb. 10A/Hayes 23B; 4. Lamb. 9A/Hayes 181; 5. tipus 31 de la vaixella culinària categoria $\mathrm{C}$ de Bonifay; 6. Ostia I, 273/Hayes 193; 7, 8, 9 i 11. Ostia III, 267A/Hayes 197; 10. Atl. CVIII, 1; 12. Hayes 131; 13. Ostia II, 302; 14. Ostia III, 332/Hayes 196; 15, 16 i 17. Ostia I, 261; 18. Ostia I, 264B; 19. Ostia I, 262/ Hayes 195. 


\begin{tabular}{|c|c|c|}
\hline $\begin{array}{l}\text { Classe } \\
\text { ceràmica }\end{array}$ & Tipus & NMI \\
\hline \multirow{13}{*}{$\begin{array}{l}\text { Comuna } \\
\text { oxidada }\end{array}$} & Ampolla & 62 \\
\hline & Escudelles & 34 \\
\hline & Cassoles baixes & 39 \\
\hline & Olles de cocció & 15 \\
\hline & $\begin{array}{l}\text { Olles } \\
\text { d'emmagatzematge }\end{array}$ & 13 \\
\hline & Tapadores & 12 \\
\hline & Tasses & 3 \\
\hline & Gerres trilobulades & 15 \\
\hline & Gerres & 223 \\
\hline & Morters & 8 \\
\hline & Urnes & 1 \\
\hline & Gibrell & 3 \\
\hline & Plat & 2 \\
\hline $\begin{array}{l}\text { Comuna ox. } \\
\text { engalbada }\end{array}$ & Escudella & 1 \\
\hline \multirow{3}{*}{$\begin{array}{l}\text { Comunes } \\
\text { africanes }\end{array}$} & Morter & 18 \\
\hline & Gibrell & 38 \\
\hline & Gerretes & 4 \\
\hline
\end{tabular}

\begin{tabular}{|c|c|c|}
\hline & Ampolla & 10 \\
\hline & Plat & 1 \\
\hline & Cassola & 4 \\
\hline & Escudella & 10 \\
\hline & Cassola baixa & 6 \\
\hline & Olleta & 1 \\
\hline $\begin{array}{l}\text { Comuna } \\
\text { eivissenca }\end{array}$ & Escudella & 1 \\
\hline Comuna itàlica & Gerreta & 1 \\
\hline $\begin{array}{l}\text { Comuna } \\
\text { reduïda }\end{array}$ & Gerretes & 2 \\
\hline \multirow[t]{6}{*}{$\begin{array}{l}\text { Grollera } \\
\text { oxidada }\end{array}$} & Escudella ansada & 49 \\
\hline & Olla cocció & 164 \\
\hline & Cassola & 14 \\
\hline & Plat? & 2 \\
\hline & Gerreta & 2 \\
\hline & Gibrell? & 2 \\
\hline \multirow[t]{2}{*}{$\begin{array}{l}\text { Grollera } \\
\text { reduïda }\end{array}$} & Escudella & 3 \\
\hline & Olla cocció & 12 \\
\hline Dolium & & 4 \\
\hline
\end{tabular}

Figura 10. Quadre amb les formes identificades de comuna, grollera i dòlia.

En aquesta categoria incloem també les ceràmiques grolleres (figura 12, 1-4). I com en el cas anterior s'identificà de cocció oxidant (cassoles, gerres, olles de cocció, un possible gibrell i un possible plat) i reductora (escudelles i olles de cocció). La pasta d'aquestes peces és un xic més grollera que la de les comunes però presenten alhora la mateixa composició. D’aquest tipus de pasta i de cocció oxidant, són també les 4 vores de doliae recuperades.

Pel que fa a les produccions de fora de l'ager Tarraconensis, cal destacar una escudella de comuna oxidada eivissenca (amb una pasta idèntica a la de les àmfores, de color clar, amb abundant presència de mica i desgreixants calcaris), una gerreta de comuna itàlica (residual) i un conjunt força nombrós de comunes africanes, on destaquem ampolles, cassoles, escudella, gerretes, gibrells, morters i plats (figura 13). Aquest tipus de producció africana, quantitativament, és molt menor que la cuina africana, i es diferencia d'aquesta, ja que presenten una pasta granulosa de color groc. La seva cronologia se situa al segle II avançat i durant la primera meitat del segle III dC (Aquilué 1995: 61; Casas et al. 1990: 244). Val a dir que en el cas concret de les peces LCB-13-2371-80 i LCB-18-2371-81, se n'han recuperat d'idèntiques — tot i que interpretades com a possibles orinals o grans recipients de funcionalitat indeterminada- a Roses, al mas de Dalt (Peratallada), a la vil.la dels Tolegassos (Viladamat) i al fòrum romà d'Empúries, totes en nivells de la segona meitat del segle III dC (Casas et al. 1990: 248-249 i 344-345). Per contra, pel que fa a la peça LCB-13-2371-79 se'n va recuperar una de semblant a la vil.la dels Tolegassos (Viladamat) però en un context de segona meitat del segle II dC (Casas et al. 1990: 318-319).

\section{Les imitacions de ceràmica africana}

La gran acceptació que la producció de ceràmica africana va tenir tant a Tàrraco com al seu territori, va provocar que diferents tallers locals imitessin tipus i formes originalment africanes (figura 14), ja des de la primera meitat del segle II dC (figura 12, 6-18). Aquest fet responia, segons X. Aquilué, a la circumstància que el mercat tenia necessitat d'aquests productes, bé perquè eren més barats o bé perquè satisfeien una demanda que els productes originaris no podien assumir (Aquilué 2008: 554). Val a dir que aquesta producció tan específica tan sols s'ha pogut identificar als centres receptors, no en canvi 


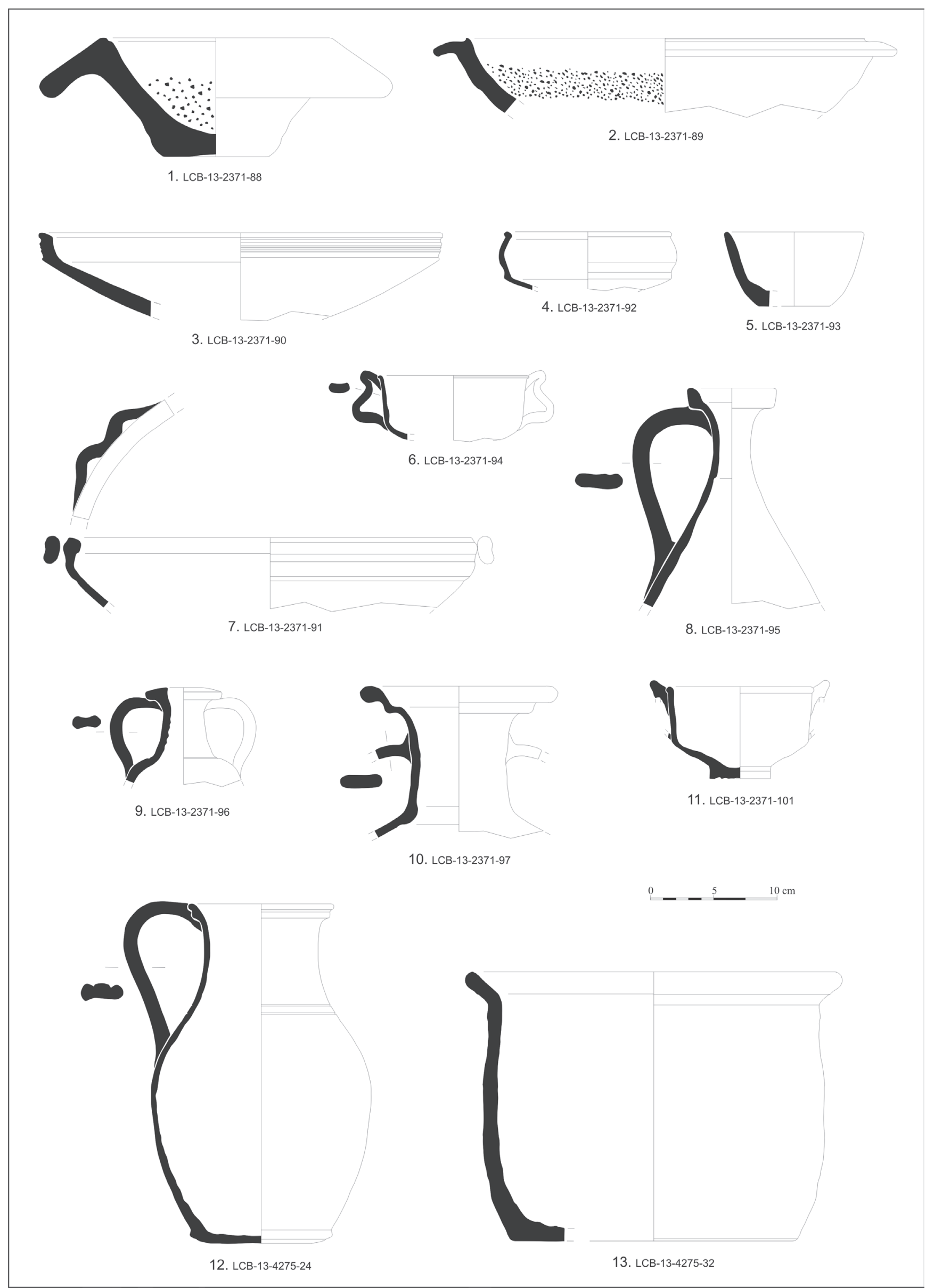

Figura 11. Comuna oxidada: 1 i 2. morter; 3 i 7. escudella carenada; 4 i 5. escudella; 6 i 11. tassa; 8 i 9 . ampolla; 10 i 12. gerreta; 13. gibrell. 


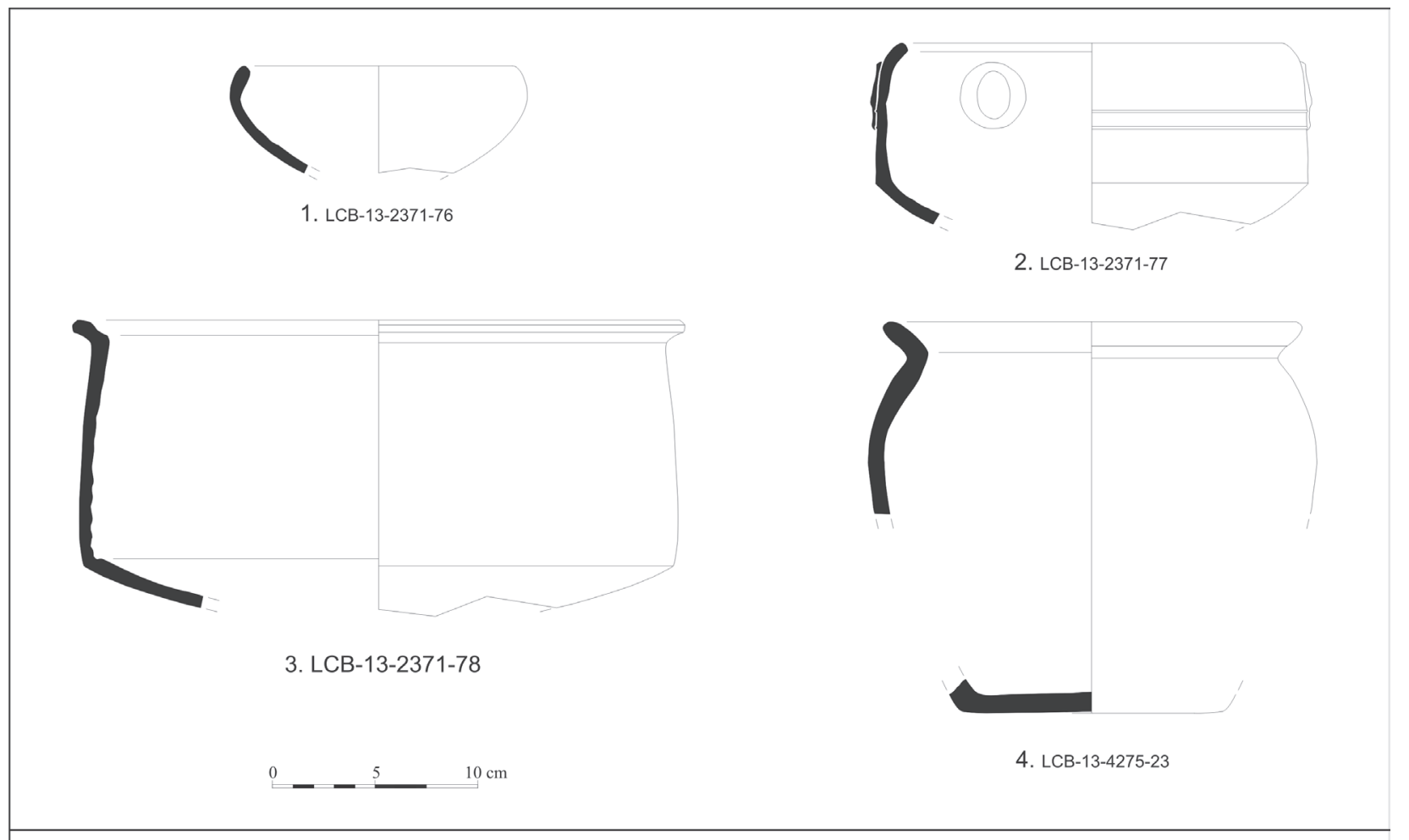

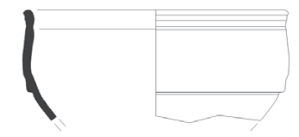

5. LCB-13-2371-22

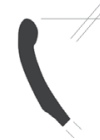

8. LCB-13-2371-25

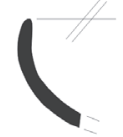

9. LCB-13-2371-26

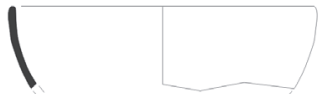

6. LCB-13-2371-23

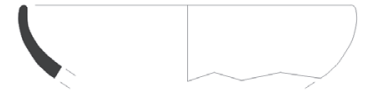

7. LCB-13-2371-24
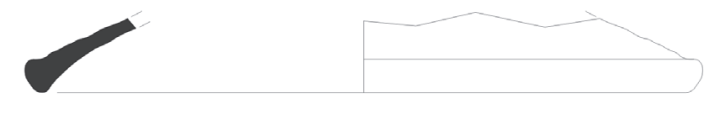

10. LCB-13-2371-27

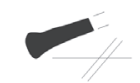

11. LCB-13-2371-28
12. LCB-13-2371-29

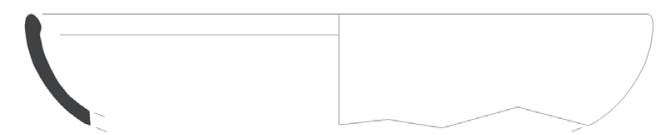

14. LCB-13-4275-12

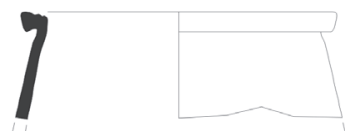

16. LCB-13-4275-14

15. LCB-13-4275-13

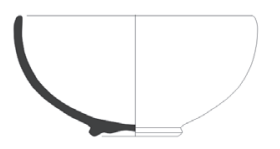

18. LCB-13-4275-31

Figura 12. Grollera reduïda: 1. escudella. Grollera oxidada: 2 i 3. escudella; 4. olla de cocció. Comuna oxidada engalbada: 5. escudella. Imitacions de ceràmica africana: 6 i 18. escudella, imitació de Lamb. 8/Hayes 17A en TS Africana A; 7. escudella, imitació d’Ostia I, 57 en TS Africana A; 8, 13 i 14. cassola, imitació de Lamb. 10A/Hayes 23B en cuina africana; 9 i 15. cassola, imitació de Lamb. 9A/Hayes 181 en cuina africana; 10, 11 i 12. tapadora, imitació d'Ostia I, 261 en cuina africana;

16. cassola, imitació d'Ostia III, 324 en cuina africana; 17. escudella, imitació de Salomonson C10 en TS Africana C. 


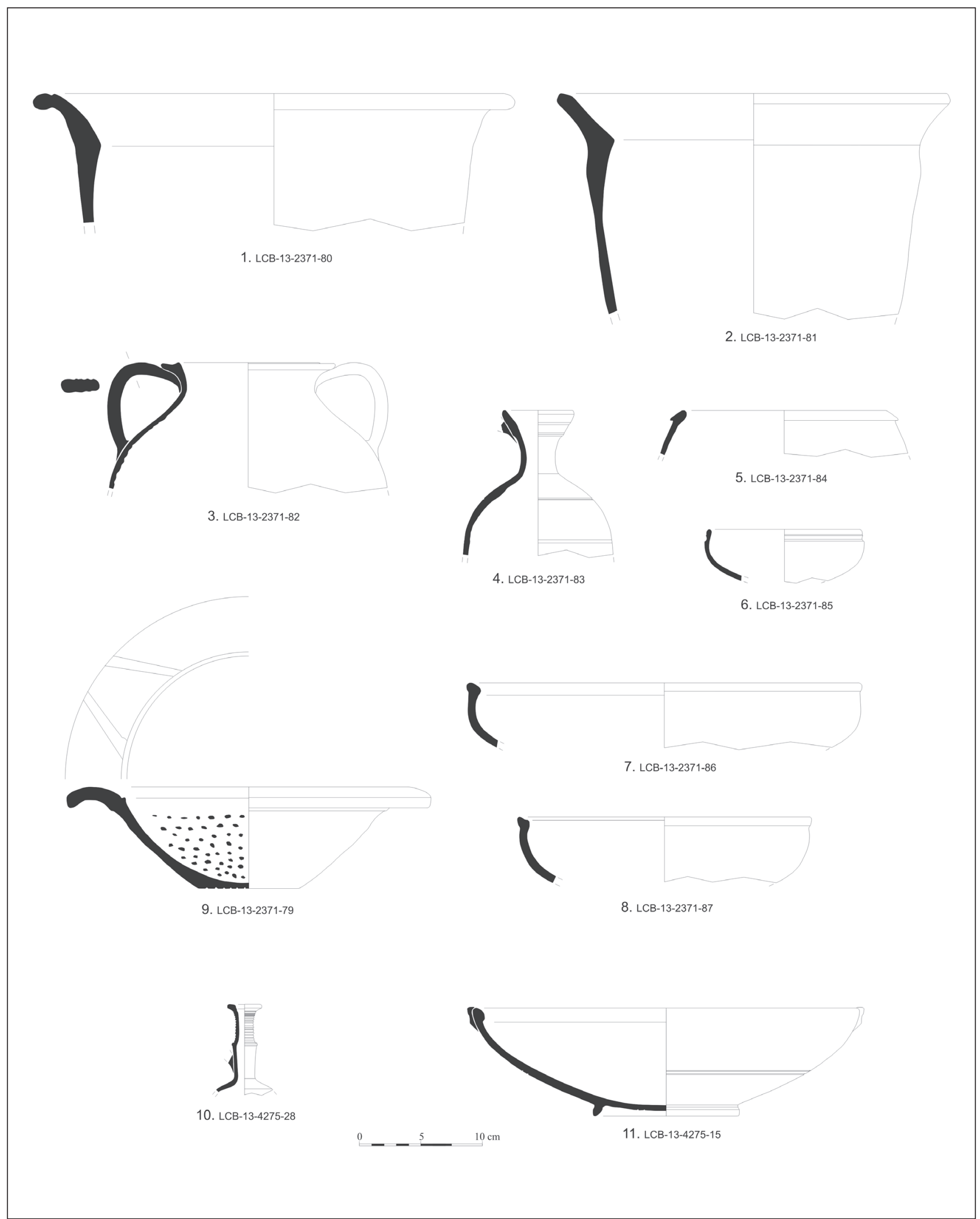

Figura 13. Comuna africana: 1 i 2. gibrell; 3. gerreta; 4 i 10. ampolla; 5, 6, 7, 8 i 11. escudella; 9. morter. 


\begin{tabular}{|l|l|l|}
\hline Classe ceràmica & Tipus & NMI \\
\hline Comuna oxidada & $\begin{array}{l}\text { Bol, imitació de Hayes 44 } \\
\text { (TS Africana C) }\end{array}$ & 1 \\
\hline & $\begin{array}{l}\text { Cassola, imitació de Lamb. } \\
10 A \text { (Cuina africana) }\end{array}$ & 3 \\
\hline & $\begin{array}{l}\text { Cassola, imitació de Lamb. } \\
\text { 9A (Cuina africana) }\end{array}$ & 2 \\
\hline & $\begin{array}{l}\text { Cassola, imitació d'Ostia III, } \\
324 \text { (Cuina africana) }\end{array}$ & 1 \\
\hline & $\begin{array}{l}\text { Escudella, imitació de } \\
\text { Lamb. 8 (TS Africana A) }\end{array}$ & 2 \\
\hline & $\begin{array}{l}\text { Escudella, imitació d'Ostia } \\
\text { I, 57 (TS Africana A) }\end{array}$ & 1 \\
\hline & $\begin{array}{l}\text { Tapadora, imitació d'Ostia I, } \\
\text { (Cuina africana) }\end{array}$ & 3 \\
\hline
\end{tabular}

Figura 14. Quadre amb les formes imitades, originalment africanes.

als productors, fet pel qual no podem especificar el lloc exacte on foren fabricades aquestes peces (Aquilué 2008: 554).

Val a dir que aquestes peces imiten formes que tenen una gran acceptació en un moment concret, fet que ens reafirma la cronologia de finals del segle III dC, ja que com hem dit més amunt, segons Atlante, les formes imitades són típiques del segle III dC (Atlante 1981: 211, 223), i en el cas concret del bol en TS Africana C tipus Hayes 44/ Lamb. 35, es proposa una datació de 220/40 - finals segle III dC (Atlante 1981: 70).

\section{Les àmfores}

Segons el nombre de fragments d'àmfora recuperats durant l'excavació de l'abocador, el 33,3\% correspon àmfora bètica, el $18,7 \%$ a àmfora africana, el 13,5\% a àmfora tarraconenses, el 13,2 \% a àmfora itàlica, el 12,1\% a àmfora indeterminada, el $6,8 \%$ a àmfora lusitana, el $2 \%$ a àmfora punicoebusitana, el $0,3 \%$ a àmfora oriental i el $0,1 \%$ a àmfora sud-gàl-lica. Si bé queda reflectit el domini, en nombre d'informes, de les àmfores amb un origen bètic, pel que fa al nombre d'individus l'àmfora més representada a l'abocador, correspon al tipus Dr. 16 B-C de producció lusitana. En segon lloc, trobem les àmfores africanes amb 19 individus i en tercer lloc les itàliques i les tarraconenses amb 17 , cadascuna. En quart lloc, les bètiques amb 6 individus, i per acabar, una sud-gàl-lica, una PE i 6 informes de la versió monoansada d'època imperial de LRA 3 (figures 15 i 16).

\begin{tabular}{|c|c|c|}
\hline Classe ceràmica & Tipus & NMI \\
\hline \multirow[t]{5}{*}{ Amfora africana } & Agora M254? & 1 \\
\hline & Dr. 30 & 7 \\
\hline & Keay $3 \mathrm{~A}$ & 1 \\
\hline & Keay 3B & 8 \\
\hline & Keay 6 & 2 \\
\hline \multirow[t]{4}{*}{ Am fora bètica } & Dr. 7-11 & 1 \\
\hline & Dr. 20 & 3 \\
\hline & Dr. $20 \mathrm{~F}$ & 1 \\
\hline & Haltern 70 & 1 \\
\hline Amfora gauloise & $?$ & 1 \\
\hline \multirow[t]{3}{*}{ Amfora itàlica } & Almond Rim & 10 \\
\hline & Dr. $2-4$ & 6 \\
\hline & Richborough 527 & 1 \\
\hline \multirow[t]{2}{*}{ Amfora lusitana } & Dr. 14 & 1 \\
\hline & Keay $16 \mathrm{~B}-\mathrm{C}$ & 29 \\
\hline Am fora oriental & LRA3? & 6 informes \\
\hline Am fora $\mathrm{PE}$ & PE 25 & 2 \\
\hline \multirow[t]{3}{*}{ Amfora tarraconense } & Dr. 2 & 14 \\
\hline & Dr. 2-4 Tardana & 2 \\
\hline & Dr. 7-11? & 1 \\
\hline
\end{tabular}

Figura 15. Quadre amb les formes d'àmfora identificades.

Donada la massiva constatació de recipients africans (ceràmica comuna, cuina africana i vaixella fina), el fet de documentar pocs individus d'àmfora africana en relació amb altres produccions com són la lusitana, la itàlica i fins i tot la tarraconense, no sabem si s'ha d'atribuir a una peculiaritat formativa del dipòsit o a un comportament general del comerç amfòric i per tant al tipus de subministrament que es distribuí al territorium de Tarraco en aquest moment cronològic.

\section{La cronologia del conjunt}

Pel que fa a la cronologia, que ja hem anat apuntant a mesura que fèiem la descripció dels diferents tipus ceràmics identificats a l'abocador, la datació 


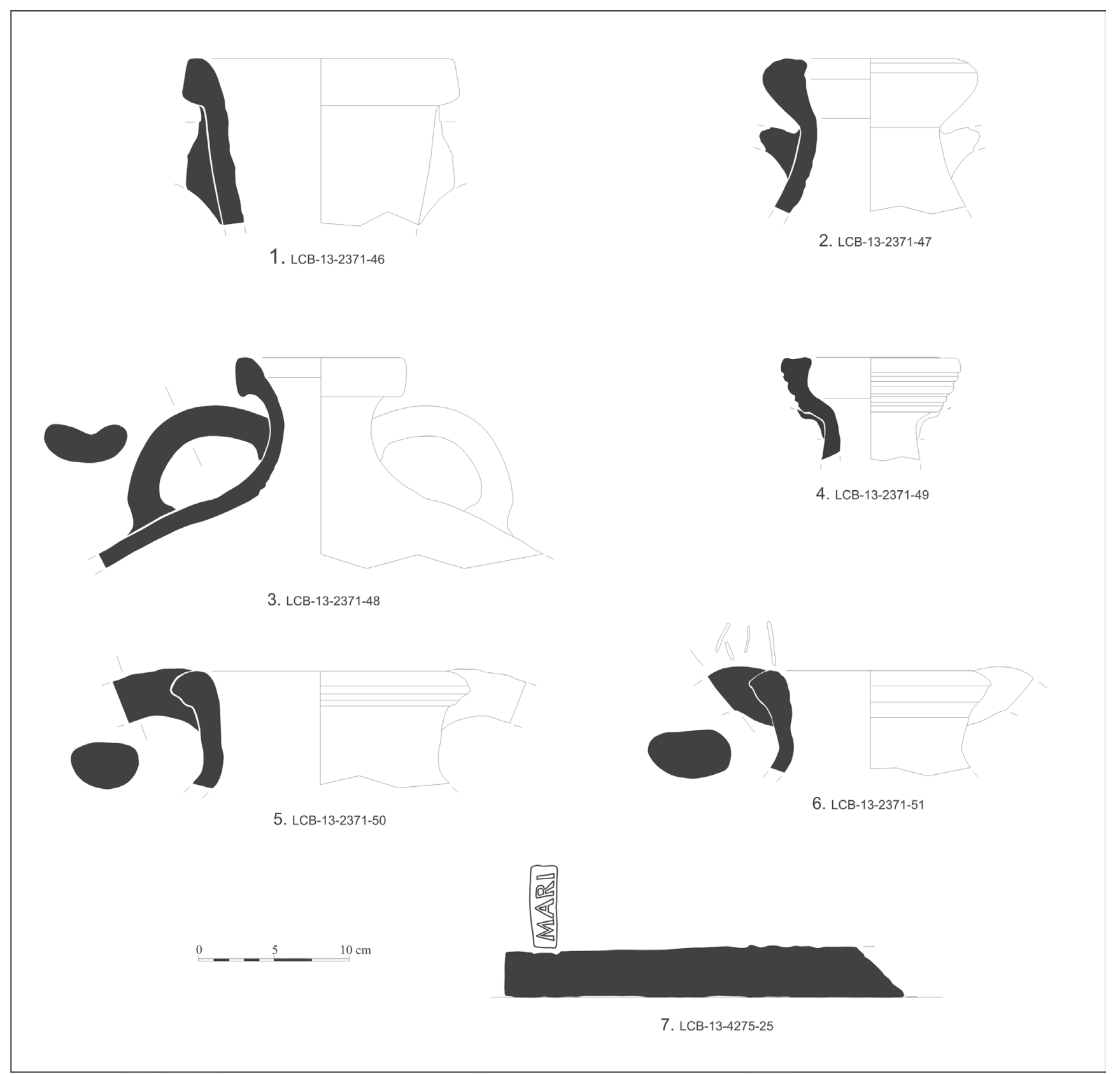

Figura 16. Àmfora tarraconense: 1. Dr. 2-4 tardana. Àmfora africana: 2. Keay 3B; 3. Dr. 30. Àmfora sud-gàl-lica: 4. tipus indeterminat. Àmfora lusitana: 5 i 6. Keay 16B-C. Tègula: 7. amb segell MARI.

proposada per a aquest dipòsit es pot situar dins el darrer terç del segle III dC, sense més precisió, ja que les tres monedes recuperades, malauradament eren totes il.legibles. ${ }^{6}$

Així doncs per tal de poder datar el moment exacte en què es formà l'abocador, ens hem de limitar a arguments de caire tipològic i comparatiu a partir de les formes ceràmiques amb cronologies més precises, i un moment final, pròxim o anterior a les darreries del segle III dC.

Aquesta cronologia ens ve definida per un conjunt concret de material ceràmic. Entre la vaixella fina, destaquem les formes plenament tardanes de TS

6. Estudi numismàtic realitzat per la nostra col-lega Imma Teixell Navarro, a qui agraïm la seva valuosa col-laboració.
Africana A: Lamb. 3a/Hayes 14A, Lamb. 3b¹/Hayes 14B, Lamb. 3b²/Hayes 14C, Lamb. 3c/Hayes 16, Lamb. 8/Hayes 17A, Lamb. 9a i 9a²/Hayes 27, Lamb. 9b/Hayes 26, Hayes 31 i Ostia I, 57 (segona meitat segle II dC - segle III dC). Per a Bonifay les formes Hayes 8/Lamb. 1C, Hayes 14C/Lamb. 3b ${ }^{2}$, Hayes 16/ Lamb. 3c; Hayes 17/Lamb. 8; Hayes 17/Ostia I, 57, Hayes 27/Lamb. 9a, Hayes 27/Lamb. 9a² i Hayes 31 es poden datar de manera genèrica dins del segle III dC (Bonifay 2004: 154-159, fig. 84-85). En TS Africana C les formes, Lamb. 40 bis/Hayes 50A de producció $\mathrm{C}^{1}$ (primera meitat del segle III - 320/330 dC) i $\mathrm{C}^{2}$ (mitjan segle III - inicis segle IV dC) (Atlante 1981: 65; Hayes 1972: 73, 289-290), Hayes 42 (220-240/250 $\mathrm{dC})$, Hayes 44/Lamb. 35 (220/240-300 dC) (Atlante 1981, 70) o un xic més enllà (Hayes 1972: 62), Hayes 45A/Lamb. 42 (220-240/250 dC) (Atlante 1981: 63), 
Hayes 48A/Lamb. 41 (220-270 dC) (Atlante 1981: 61; Hayes 1972: 67) i Hayes 50 (230/240-325 dC) (Atlante 1981: 65). En TS Africana A/D les formes Hayes 32 (primera meitat del segle III dC, Bonifay 2004: 162, fig. 88; Hayes 1972: 55) i Hayes 33 (primera meitat del segle III dC, Hayes 1972: 55-56). Ambdues formes són per a Atlante molt comunes i típiques dins del segle III dC (Atlante 1981: 52-53). I en TS Hispànica Tardana, les formes Drag. 37a i Ritt. 8, segons Paz Peralta, amb una cronologia de circa 250-circa 330 dC (Paz Peralta 2008: 502-506, 512-516).

Gairebé la totalitat de les cuines africanes de l'abocador tenen una cronologia força àmplia, fet que no ens permet precisar el moment que es va formar l'abocador. Tot i així diferents autors (Aguarod 1991; Aquilué 1992a i 1995; Atlante 1981; Bonifay 2004; Serrano 2005) consideren que hi ha un conjunt de formes que són típiques del segle III dC, com són el plat tapadora Ostia I, 261, la cassola alta Ostia III, 267/Hayes 197, la marmita Ostia I, 56 i les cassoles baixes Lamb. 9A/Hayes 181, Lamb 10A/Hayes 23B i en menor mesura Lamb. 10B/Hayes 23A. Però val a dir que altres formes també són presents - fins i tot força comunes- en aquestes cronologies, com són els plats tapadora Ostia I, 20/Hayes 185 (Atlante 1981: 212; Bonifay 2004: 221-222, fig. 118), Ostia III, 332 (Aquilué 1995: 67) i Ostia III, 170 (Aquilué 1995: 67), Ostia I, 264 (Atlante 1981: 214; Serrano 2005: 263) i Ostia I, 262 (Aquilué 1995: 67; Atlante 1981: 213; Bonifay 2004: 216-217, fig. 115; Serrano 2005: 262); la tassa Hayes 131 (Aquilué 1995: 67), l'olla Hayes 200 (Aquilué 1995: 70), i les cassoles Ostia I, 270 (Aquilué 1995: 68; Atlante 1981: 221; Serrano 2005: 266), Ostia I, 273 (Aquilué 1995: 69; Atlante 1981: 222; Bonifay 2004: 211-212, fig. 112; Serrano 2005: 265), Ostia III, 108 (Aquilué 1992a i 1995: 69; Serrano 2005: 266-267), Atl. CVIII, 1 (Aquilué 1995: 69; Serrano 2005: 267), Atl. CVIII, 2 i Ostia I, 278 (Atlante 1981: 222). Aquesta darrera forma correspon també a la variant més primerenca del tipus 31 de la vaixella culinària categoria $\mathrm{C}$ de Bonifay, amb una cronologia de primera meitat o mitjan del segle III dC (Bonifay 2004: 238-239, fig. 128).

Dins del món de les àmfores, cal valorar les de producció africana, formes Dressel 30/Keay 1A (difícil precisió cronològica, tot i així es proposa un origen de finals del segle II - primera meitat del segle III i genèrica de mitjan segle III dC, Bonifay 2004: 148151, fig. 81), Keay 3A (tipus Africana I, variant A de Bonifay amb una cronologia de finals del segle II - inicis del segle III dC, Bonifay 2004: 107, fig. 56), Keay 3B (tipus Africana I, variant B de Bonifay de mitjan segle III dC, Bonifay 2004: 106-107, fig. 56) i Keay 6 (tipus Africana IIC, variant C1 de Bonifay, i una cronologia de mitjan segle III dC - inicis del segle IV dC Bonifay 2004: 111-115, fig. 60). Segons Remolà, les formes Keay 3A, Keay 3B i Keay 6, són freqüents en contextos del segle III i part del IV dC (Remolà 2000a: 110, 112-113, fig. 17, 1-9; 24, 1-9). Dins de la producció lusitana, destaquem les formes Keay 14 i Keay 16A (per a Remolà aquest darrer tipus és pràcticament nul en contextos tardans, fet que ens confirmaria la cronologia de segle III dC,
Remolà 2000a: 145, nota al peu número 292). Pel que fa a les àmfores de producció itàlica, destaquem la forma Almond Rim, un tipus amfòric ben datat a partir d'un titulus pictus amb data consular del 216 dC, a més de ser força conegudes a Ostia, en contextos entre el 230 i el 283 dC (Arthur 1987: 401-406; 1992: 250-260).

I en darrer lloc, com ja hem dit més amunt, les comunes africanes es poden situar entre el segle II dC avançat i la primera meitat del segle III dC (Aquilué 1995: 61; Casas et al. 1990: 244). Tot i així algunes formes, segons Bonifay, es poden datar dins del segle III dC. Com poden ser el gibrell LCB-13-2371-80 (comuna tipus 22, forma Uzita 3, variant A, Bonifay 2004: 263-265, fig. 144), l'ampolla LCB-13-4275-28 (tipus 48-49, Bonifay 2004: 283 i 285, fig. 157, 2) i els bols/escudelles LCB-13-2371-86 i 87 (forma Uzita 1, Bonifay 2004: 245-246, fig. 132, 4).

\section{Conclusions}

L'objectiu d'aquest treball ha estat el de conèixer un conjunt tancat de materials procedents d'un abocador format a finals del segle III $\mathrm{dC}$, amb posterioritat a un moment de destrucció de diferents àmbits domèstics de caire privat de la pars urbana de la vil.la dels Castellets (figura 2), causat molt probablement per la invasió franca (Roig et al. en premsa).

L'estudi dels materials ceràmics exhumats en aquest abocador ens permet conèixer les diferents formes i tipologies ceràmiques d'ús quotidià més corrents i característiques d'una vil.la de l'ager Tarraconensis a les darreries del segle III dC.

Pel que fa al repertori formal, veiem que predominen per sobre de tot les produccions ceràmiques de l'Africa Proconsularis i de la Byzacena. Un fet que es repeteix a la ciutat romana de Tarragona, tal com han evidenciat el gran nombre d'intervencions arqueològiques dutes a terme en els darrers anys. En aquest sentit, l'epigrafia de Tarraco del segle II dC ens ha permès comprendre una realitat econòmica, comercial i social confirmada per la residència i l'exercici de càrrecs públics per part de ciutadans romans originaris del nord d'Àfrica (Aquilué 1992b: 27-28; RIT 339, RIT 402, RIT 135, RIT 187, RIT 189 i RIT 229).

S'observa un predomini absolut de les produccions africanes, tant pel que fa a la vaixella fina (el 85,5\% del total de la vaixella i el $5 \%$ de la totalitat de l'abocador) com a la ceràmica de cuina africana (el $56 \%$ del total de les ceràmiques comunes i el $35 \%$ de la totalitat de l'abocador). Un domini que queda confirmat també per les imitacions locals de formes africanes, ja que tal com hem vist més amunt, en tots els casos les imitacions responen a còpies de formes africanes.

Dins de la vaixella fina, la TS Africana A és la classe ceràmica més representada, amb el 71,5\% del total. A continuació trobem la resta de produccions africanes, la TS Africana C i TS Africana A/D, entre les dues sumen el $14 \%$ del total de la vaixella fina. La TS Africana A és també la que presenta més varietat tipològica, ja que se n'han identificat 19 formes diferents (amb un predomini de les més tardanes) 
respecte a les 8 de les TS Africana $\mathrm{C}$ i les 3 de les TS Africana A/D.

Pel que fa a la categoria de les cuines africanes, aquest és el tipus ceràmic més nombrós, tant en nombre de fragments (6.257) com d'individus (2.314), varietat tipològica (22) i amb una cronologia global de segles I-III dC. Dins d'aquesta categoria, cal evidenciar el gran nombre de cassoles altes Ostia III, 267B/Hayes 197 (500 individus) i de plats tapadora Ostia I, 261 (716 individus) exhumats, unes peces que com ja hem apuntat anteriorment formarien part d'un mateix servei.

Aquest domini absolut presenta una excepció, les àmfores. El nombre de fragments corresponents a àmfores africanes és del 18,7\% del total, per darrere de les àmfores de procedència bètica, amb un 33,3\% . Una segona posició que es manté també pel que fa al nombre d'individus, 19 (1 Àgora M254?, 1 Keay 3A, 2 Keay 6, 7 Dr. 30 i 8 Keay 3B), respecte als 29 corresponen al tipus Dr. 16 B-C de producció lusitana.

Resumint, observem com a les darreries del segle III $\mathrm{dC}$, encara té un paper molt destacat la TS Africana A, tot i que conviu plenament amb les TS Africana C. S'evidencia també l'abundant nombre de recipients de cuina africana $\mathrm{i}$ - tot i que en menor proporcióde comunes de procedència nord-africana. Pel que fa al món amfòric, encara hi ha una perduració de les Dr. 20 tot i que el protagonisme cau novament en les produccions africanes $\mathrm{i}$ tripolitanes (Keay 3A, Keay 3B, Keay 4 i Keay 6), itàliques (Almond Rim) i sobretot lusitanes (Keay 16A).

Per acabar, donem un cop d'ull ràpid a alguns conjunts amb cronologies semblants que a més d'ajudar-nos a constituir bons paral-lels per al nostre abocador, ens permetin conèixer les diferents formes ceràmiques d'ús quotidià més corrents i característiques d'una vil.la de l'ager Tarraconensis a les darreries del segle III dC. En aquest sentit hem de dir que el material ceràmic d'aquest abocador coincideix mutatis mutandis amb alguns dels estrats de destrucció associats a la invasió franca (Macias et al. 2013: 193-214) documentats tant a la ciutat de Tarraco com al seu ager. En destaquem tres exemples, ${ }^{7}$ dos els trobem a Tarraco, fora muralles (carrer Castaños i entorn del Mercat Central) i un tercer, en una de les vil.les litorals del territorium de Tarraco, la Llosa de Cambrils.

L'abocament de residus excavat al número 1 del carrer Castaños, a cavall dels anys 1999 i 2000, esdevé un dels conjunts ceràmics més importants que es coneixen a la ciutat de Tarragona. Els seus excavadors el daten en un moment avançat de la segona meitat del segle III dC, a partir de l'aparició de determinades formes (uide infra) així com de l'absència d'importacions de TSA D. Es tracta d'un conjunt força homogeni on també s'evidencià material residual i d'altres produccions ceràmiques més pròpies del segle II $\mathrm{dC}$.

7. Val a dir que per a aquests tres exemples no enumerarem la totalitat del material ceràmic recuperat, sinó que tan sols farem esment d'aquelles peces que ens permeten precisar la data del conjunt, ja que amb aquest treball no pretenem fer un estudi ceràmic de caire estadístic ni tipològic de cadascun d'ells, i sí precisar-ne la cronologia. Per a saber-ne més, convidem el lector a consultar la bibliografia associada en cada cas.
Un exemple el trobem en el cas de les àmfores, on l'estudi del material identificà una certa convivència entre envasos característics del segle III (Keay 3, 4, $5,6,7,13)$ amb d'altres més freqüents del segle II dC (PE 25, Dr. 2-4, Dr. 20, etc.). En aquest sentit, tal com indiquen els seus excavadors, la composició tipològica d'aquest abocador permet qüestionar la perdurabilitat cronològica de determinades peces (Macias 2004: 86-88). ${ }^{8}$

De tot aquest gran conjunt ceràmic, en l'àmbit cronològic en destaquem, en TS Africana A, les formes tardanes Hayes 14/17, Hayes 14b, Hayes 31, Lamb. 3a, Lamb. 3b ${ }^{1}$, Lamb. 3b ${ }^{2}$, Lamb. 3c, Lamb. 3c $c^{1}$, Lamb. 3/8, Lamb. 8, Lamb. 9, Lamb. 9a, Lamb. 9a², Lamb. 9b; en TS Africana A/D, les formes Atl. XXV,10 i Hayes 31; en TS Africana C, les formes Hayes 42, Hayes 48b, Hayes 49, Lamb. 40bis, Lamb. 41, Lamb. 42, Sal. C3, Sal. C8 i Var. Lamb. 35; en TS Africana C/E, la forma Hayes 58; en TS Lucente, la forma Lamb. 1/3C; en ceràmica coríntia, la forma Spit. 1942, 170, 1; en cuina africana, les formes, Atl. CVII, 12, Atl. CVIII,1, Ostia I, 264, Ostia I, 267, Ostia I, 273, Ostia IV, 59 i Ostia IV, 61. Pel que fa a les àmfores destaquem les de producció africana tipus Keay 1B, Keay 3A, Keay 3B, Keay 5, Keay 6 i Keay 7; i les de producció bètica tipus Beltrán 68, Dressel 23 i Keay 16A.

L'any 2008, durant l'excavació de la domus datada entre els segles I i II dC, documentada a les àrees d'intervenció 5A i 5B del Mercat Central de Tarragona, es va recuperar dins d'un nivell d'incendi un tresoret amb 12 antoninians i una data de tancament per al moneder de l'any 266 dC (Brú et al. 2012: 313-335; Teixell 2012: 87-103).

El conjunt ceràmic recuperat en aquest estrat de destrucció es caracteritza per les següents classes ceràmiques. En cuina africana, les formes Lamb. 10B, Ostia I, 261, Ostia III, 332 i Ostia III, 267A. I en àmfores, el tipus Dr. 2-4 Tardana de producció tarraconense.

Val a dir que en aquesta mateixa zona, però a l'àrea d'intervenció 2 , els treballs arqueològics van permetre reconèixer diferents farciments constructius formats a partir de l'enderroc de la domus identificada a les àrees 5A i 5B. L'estudi del material numismàtic ha permès datar aquesta nova fase arquitectònica, i per tant la recuperació d'aquest sector de la Tarragona romana, a partir del $276 \mathrm{dC}$ (Teixell 2012: 87-103). Pel que fa a la ceràmica, el material recuperat també ens permet datar aquest moment dins el darrer terç del segle III dC. En destaquem l'exhumació de les següents tipologies ceràmiques. En cuina africana, la forma Ostia I, 264a; en TS Africana A, les formes tardanes Hayes 16, Hayes 31, Lamb. 3b ${ }^{1}$, Lamb. 3b ${ }^{2}$, Lamb. 3c, Lamb. 3c ${ }^{1}$, Lamb. 3/8, Lamb. 8, Lamb. 9a i Ostia I, fig. 86; en TS Africana A/D, la forma Hayes 32; en TS Africana C, les formes Hayes 50, Hayes 50B i Lamb. 40 bis; i en TS Hispànica Tardana, les formes Drag. 37 i Ritt. 8. I dins del món de les àmfores, destaquem les Keay 3A, Keay 3B i Keay 7 de producció africana i la Keay 23 de producció bètica.

8. Pensem que una anàlisi similar es podria fer per a l'abocador de la vil-la dels Castellets. 
Entre els anys 2003 i 2009, a la vil.la romana de la Llosa, s'excavà una zona al nord de les restes museïtzades el desembre del 2003. En aquest sector els treballs arqueològics identificaren un nivell d'incendi i posterior enderroc. ${ }^{9}$

Degut a les característiques formatives del nivell d'incendi identificat, es van recuperar pocs exemplars ceràmics. Tot i així en destaquem, dins de les cuines africanes, les formes Lamb 10A, Lamb 10B, Ostia I, 261, Ostia III, 267A, Ostia III, 267B i Ostia III, 332; i dins de la producció TS Africana A, les formes Lamb. 3a, Lamb. 3b1, Lamb. 4/36B, Lamb. 8 i Lamb. 23. Cal enumerar també la recuperació d'una moneda encunyada en el decurs del regnat de Gordià III (238-244 dC).

Més prolífica, en l'àmbit ceramològic, va ser l'excavació del nivell d'enderroc identificat per sobre del nivell d'incendi exposat anteriorment. El conjunt ceràmic associat a aquest moment cronològic es caracteritza per contenir, com és evident, un gran nombre de fragments de caire constructiu (tegulae, imbrices, bessales, bipedales, restes de morter, restes de pintura mural i tessel.les), però també elements metàl-lics, vaixella vítria, fauna i un gran volum de material ceràmic, on destaquem dins de la cuina africana les formes Ostia IV, 1, Ostia IV, 59 i Ostia IV, 61; dins de les TS Africanes A, identifiquem les formes tardanes Lamb. 3a, Lamb. 3b, Lamb. 3b1, Lamb. 3b2, Lamb. 3/8, Lamb. 8, Lamb. 9a, Lamb. 9b, Hayes 14B, Hayes 16?, Hayes 31 i Hayes 32; de la producció TS Africana A/D, la forma Hayes 31; dins de les TS Africana C, les formes Lamb. 40 Bis i Hayes 50B; i finalment, de la Terra Sigillata Hispànica Tardana, en destaquem la forma Ritt. 8. Quant a les àmfores s'exhumaren les formes Keay 4 i Keay 6 de procedència africana i la forma Keay 23 de procedència lusitana. A més, aquest nivell d'enderroc també fou molt generós pel que fa a la recuperació de monedes, ja que s'identificà un sesterci d'Adrià (amb data d'emissió del 119-138 dC), dos sestercis de Sever Alexandre (un amb data d'emissió del 228 dC i l'altre del $232 \mathrm{dC}$ ), un sesterci de Gordià III (del $241 \mathrm{dC}$ ) i un tresoret compost per 14 sestercis de bronze (3 de Trajà, 1 d'Adrià, 1 de Còmmode, 1 de Caracal.la, 3 de Sever Alexandre, 1 de Maximí, 2 de Gordià III, 1 de Filip II i 1 indeterminat) i un Antoninià (il.legible) amb una datació que se situa entre el $250 \mathrm{i}$ el $260 \mathrm{dC}$ (Garcia et al. 2013: 288-292).

Fora dels límits de l'ager Tarraconensis també s'han identificat conjunts ceràmics amb aquesta cronologia. A continuació, n'exposem dos exemples. El primer, amb una datació del darrer terç del segle III dC, fou recuperat de l'interior d'una cisterna al fòrum d'Emporiae (Aquilué et al. 1984: 465-467). En TS Africana A en destaquem les formes Hayes 15 i Hayes 16; en TS Africana C la forma Hayes 50; en cuina africana, les formes Lamb. 10A, Ostia I, 273, Ostia III, 332 i Ostia III, 267; i en àmfores el tipus Dr. 23 de producció bètica i els tipus Dr. 30 i Africanes I i IIA de producció africana. Val a dir que aquest conjunt, gràcies a l'estudi numismàtic, fou precisat cronològicament entre el 270 i el 275 dC (Nolla, Aquilué 1985: 56). El segon exemple fou documentat a la torre romana de Casa Pastors de Girona i amb una cronologia entre el 260 i 290/300 dC (Nolla, Nieto 1979: 263-283). De la totalitat del conjunt ceràmic en destaquem les formes Hayes 9B, Hayes 14A, Hayes 16, Hayes 15, Hayes 26/27 i Hayes 31 en TS Africana A; les formes Hayes 48A, Hayes 48B i Hayes 50A en TS Africana C; i les formes Lamb. 9A, Lamb. 10A/ Hayes 23B, Lamb. 10B/Hayes 23A i Hayes 185/Ostia I, 20 en cuina africana. 


\section{Bibliografia}

Adserias, M. (1998). Evidències del passat. Prehistòria i món antic a Vila-Seca. Monografies de Vila-Seca, 20.

Adserias, M., Ferrer, C., García, M., Otiña, P. (2002). Els balnea tardoantics del sector sud-occidental de Tarraco. Empúries, 53. La gestió de l'aigua a les ciutats romanes (Barcelona): 56-65.

Adserias, M., García, M., Teixell, I. (2001). Noves troballes d'època romana a l'entorn de Tàrraco: les villae del Mas dels Canonges i del Camí Vell de Salou (Tarragona, Tarragonès. Butlletí Arqueològic, èp. V, 23 (Tarragona): 213-247.

Aguarod, C. (1991). Cerámica romana importada de cocina en la Tarraconense. Institución Fernando el Católico 1281. Saragossa.

Amigo, R. (1978). Toponímia de Vila-seca de Solcina $i$ del seu terme municipal. Monografies de Vila-seca-Salou, 6. Vila-seca-Salou.

AquiluÉ, X. (1985). Algunas consideraciones sobre el comercio africano. Tres facies características de la cerámica común africana de época alto-imperial. Empúries, 47: 210-221.

Aouilué, X. (1987). Las cerámicas africanas de la ciudad romana de Baetulo (Hispania Tarraconensis). B.A.R. International Series, 3337. Oxford.

Aquilué, X. (1992a). Las cerámicas de producción africana procedentes de la Colonia Iulia Urbs Triumphalis Tarraco. Cole. T. D. microfitxades 1275. Barcelona.

AquiluÉ, X. (1992b). Comentaris entorn la presència de les ceràmiques de producció africana a Tàrraco. A: Miscel-lània Arqueològica a J. M. Recasens: Edicions El Mèdol. Tarragona: 25-33.

Aquilué, X. (1995). La cerámica común africana. A: Ceràmica comuna romana d'època alto-imperial a la Península Ibèrica. Estat de la Qüestió. Monografies Emporitanes, VIII. Barcelona: 61-74.

Aquilué, X. (2008). Las imitaciones de cerámica africana en Hispania. A: Bernal, D. i Ribera, A. (eds.). Cerámicas hispanorromanas. Un estado de la cuestión. XXVI Congreso Internacional de la Asociación Rei Cretariae Romanae Fautores. Universidad de Cádiz. Cadis: 553-561.

Aquilué, X., Mar, R., Nolla, J. M., Ruiz de Arbulo, J., SANMARTí, E. (1984). El fòrum romà d'Empúries (excavacions de l'any 1982). Una aproximació arqueològica al procés històric de la romanització al nord-est de la península ibèrica. Monografies Emporitanes. Barcelona.

ARTHUR, P. (1987). Precisazioni su di una forma anforica medio-imperiale dalla Campania. A: El vi a l'antiguitat. Economia, producció i comerç al Mediterrani occidental.
Actes I Col-loqui d'arqueologia romana. Monografies Badalonines, 9. Badalona: 401-406.

Arthur, P., Williams, D. F. (1992). Campanian wine, Roman Britain and the Third century A.D. Journal of Roman Archaeology, 5 (Portsmouth): 250-260.

Atlante (1981). Carandini, A. (a cura di). Atlante delle forme ceramiche I: Ceramica fine romana nel Bacino Mediterráneo (Medio e Tardo Impero). Enciclopedia dell'Arte Antica, Classica e Orientale. Roma.

BONIFAY, M. (2004). Études sur la cerámique romaine tardive d'Afrique. B.A.R. International series 1301. Oxford.

Bosch, F., Díaz, M., Macias, J. M. (2009). La vil.la romana de la Burguera (Salou, Ager Tarraconensis): avanç preliminar. A: Revilla, V., González, J. R., Prevosti, M. (ed.). Actes del Simposi: Les vil.les romanes a la Tarraconenses, vol. II. Monografies 11. Museu d'Arqueologia de Catalunya-Barcelona i Institut d'Estudis Ilerdencs: 155-163.

Brú, M., Garcia, M., Roig, J. F., Teixell, I. (2012). Noves dades sobre les àrees residencials de la ciutat de Tàrraco. Tribuna d'Arqueologia 2010-2011. Direcció General del Patrimoni Cultural. Servei d'Arqueologia. Generalitat de Catalunya. Barcelona: 313-335.

Casas, J., Castanyer, P., Nolla, J. M., Tremoleda, J. (1990). Ceràmiques comunes $i$ de producció local d'època romana. I. Materials augustals $i$ altoimperials a les comarques de Girona. Centre d'Investigacions Arqueològiques de Girona 12. Girona.

Casas, J., Castanyer, P., Nolla, J. M., Tremoleda, J. (1995). Les ceràmiques comunes locals del N.E. de Catalunya. A: Ceràmica comuna romana d'època altoimperial a la península Ibèrica. Estat de la qüestió. Monografies Emporitanes VIII. Museu d'Arqueologia de Catalunya. Barcelona: 99-127.

Casas, J., Merino, J. (1990). Troballes de ceràmica vidriada d'època romana a les comarques costaneres de Girona. Cypsela, VIII (Girona): 139-155.

Casas, J., Nolla, J. M. (1986-1989). Un conjunt tancat amb ceràmica africana a la villa romana dels Tolegassos (Viladamat, Alt Empordà). Empúries, 48-50, vol. I: 202-213.

Casas, J., Nolla, J. M. (2012). Cerámica común altoimperial en el nordeste peninsular. A: BERnAL, D. i RiberA, A. (eds.). Cerámicas hispanorromanas II. Producciones regionales. Monografías Historia y Arte. Universidad de Cádiz, Cadis: 469-485.

Celis, R. (2005). Las lucernas. A: Roca, M.; Fernández, A. I. (coords.). Introducción al estudio de la cerámica romana. Una breve guía de referencia. CVDAS, revista de Arqueología e Historia. Universidad de Málaga: 407-464. 
Cerdà, J. A., García, J., Martí, C., Pujol, J., Pera, J., Revilla, V. (1998). El Cardo Maximus del la ciutat romana d'Iluro (Hispania Tarraconensis). Laietania 10, 3 vol. Mataró.

ChAVARRÍA, A. (1996). Transformaciones arquitectónicas de los establecimientos rurales en el nordeste de la Tarraconensis durante la Antigüedad Tardía. Butlletí de la Reial Acadèmia Catalana de Belles Arts de Sant Jordi, X: 162-202.

Chavarría, A. (2001). Poblamiento rural en el territorium de Tarraco durante la antigüedad tardía. Arqueología y Territorio Medieval, 8: 55-76.

CODEX (2013). Informe de la intervenció arqueològica realitzada a la Nova Planta de Kemira Iberica, S.A. a La Canonja (La Canonja, Tarragonès). Informe inèdit lliurat a la Direcció General del Patrimoni Cultural. Tarragona.

Desbat, A. (1986). Cerámiques romaines à glaçure plombifère de Lyon et de Vienne. A: Societé Française d'Etude de la Céramique Antique en Gaule, Actes du Congrès de Toulouse. Tolosa: 33-39.

DíAz, M., Macias, J. M. (2000). La vil.la romana de la Pineda/Cal-lípolis (Vila-seca, Tarragonès). A: Remolà, J. A. (coord.). El territori de Tarraco: vil.les romanes del Camp de Tarragona. Forum. Temes d'Història i d'Arqueologia Tarragonines 13. Museu Nacional Arqueològic de Tarragona. Tarragona: 133-152.

García, M., Macias, J. M., Teixell, I. (1999). Necròpolis de la vil.la dels Munts. A: Del romà al Romànic. Història, art i cultura de la Tarraconense mediterrània entre els segles IV $i$ x. Enciclopèdia Catalana. Barcelona: 278-279.

García, M., Macias, J. M., Menchon, J., Puche, J. M., Ramon, E., Remolà, J. A. (2001). Cambrils. La vil.la romana de La Llosa. Deu anys d'investigació arqueològica, Ajuntament de Cambrils. Cambrils.

García, M., Roig, J. F., Teixell, I. (2013). Darreres aportacions en l'estudi de la vil.la romana de la Llosa (Cambrils, Baix Camp): l'edifici septentrional. A: Actes del Simposi internacional "L'Ager Tarraconensis. Paisatge, poblament, cultura material i història". Institut Català d'Arqueologia Clàssica. Tarragona: 281-294.

GARcíA-EnTERo, V. (2005-2006). Las transformaciones de los balnea rurales domésticos durante la antigüedad tardía en Hispania (SS. IV-VI). CuPAUAM, 31-32: 61-82.

GiBert, A. M. (1900). Ciutats focenses del litoral cossetà. Barcelona.

GonzÁlez, R. (1990). El vertedero de la Avenida de España, 3 y el siglo III $d$. de $C$. en Ebusus. Trabajos del Museo Arqueológico de Ibiza 22. Eivissa.

Granados, J. O. (1979). Cerámica corintio-romana en el Levante de la Península Ibérica. Saguntum, 14 (València): 203-219.
Hayes, J. (1972). Late Roman Pottery. A Catalogue of Roman Fine Wares, British School at Rome. Londres.

Hayes, J. (1980). A Supplement to Late Roman Pottery, British School at Rome. Londres.

IPAC. (1990). "Inventari del Patrimoni Arqueològic del Tarragonès. A: Inventari del Patrimoni Arqueològic de Catalunya. Servei d'Arqueologia de la Generalitat de Catalunya. Tarragona.

JÁRREGA, R. (2003). Las últimas importaciones romanas de cerámica en el este de hispania Tarraconensis: una aproximación. SPAL, 22 (Sevilla): 143-172.

JárRega, R. (2014). Les ceràmiques. Un exemple de l'activitat comercial a l'Ager Tarraconensis. A: JÁRREGA, R., Prevosti, M. (eds.). Ager Tarraconensis 4, Els Antigons, una vil.la senyorial al Camp de Tarragona. Documenta 16. Institut Català d'Arqueologia Clàssica, Tarragona: 55-183.

JÁRREGA, R. (2014). Revisión crono-tipológica de un grupo de cerámicas africanas de cocina: la forma Ostia I, 272 - Atlante CVII, 11-12. Quaderns de Prehistòria i Arqueologia de Castelló, 32 (Castelló): 67-75.

JÁrRegA, R., Buffat, L. (2012). La cerámica común tarraconense (Com.Ox.Tarr./Com.Red.Tarr.) y su variante con decoración pintada ( $\mathrm{Cmg})$. A: BERNAL, D. i Ribera, A. (eds.). Cerámicas hispanorromanas II. Producciones regionales. Monografías Historia y Arte. Universidad de Cádiz. Cadis: 453-468.

JÁrrega, R., SÁnchez, E. (2008). La vil.la romana del Mas d'en Gras (Vila-seca, Tarragona). Hic et Nunc 3. Institut Català d'Arqueologia Clàssica. Tarragona.

JoRDÀ, A. (1992). El "Repertorio para quedar en el Archivo parroquial de Vilaseca" de Mn. Salvador Babot (1796-1874). Monografies de Vila-seca, 16. Vila-Seca.

KEAY, S. (1984). Late roman amphorae in the Western Mediterranean. A typology and economic study: the Catalan evidence. B.A.R. International Series 196. Oxford.

KeAY, S. (2004). El territorio. A: Dupré, X. (ed.). Tarragona. Colonia Iulia Urbs Triumphalis Tarraco, Las capitales provinciales de Hispania 3. "L'ERMA" di Bretschneider. Roma: 97-109.

López, J. (2006). El poblament rural del Camp de Tarragona en època romana: assaig de síntesi. Butlletí Arqueològic, èp. V, 28 (Tarragona): 97-135.

LóPEZ, J., Piñol, Ll. (1995). El món funerari en època tardana al Camp de Tarragona. Butlletí Arqueològic, èp. V, 17 (Tarragona): 65-120.

MAcias, J. M. (1999). La ceràmica comuna tardoantiga a Tàrraco. Anàlisi tipològica i històrica (segles V-VII). TULCIS. Monografies Tarraconenses 1, MNAT. Tarragona.

MACIAS, J. M. (2000). La vil.la romana de Cal.lípolis (Vila-seca, Tarragonès). A: Tàrraco 99. Arqueologia d'una 
capital provincial romana. Documents d'Arqueologia Clàssica 3. Tarragona: 207-222.

Macias, J. M. (2004). Les termes públiques de l'àrea portuària de Tàrraco. Carrer de Sant Miquel de Tarragona. Documenta 2. Institut Català d'Arqueologia Clàssica. Tarragona.

Macias, J. M. (2005). Els assentament romans com a espai de residència: l'exemple del Territorium de Tàrraco. Cota Zero. Revista d'Arqueologia i Ciència, 20 (Barcelona): 78-86.

Macias, J. M. (2010). L'arquitectura termal a Tarraco i el seu Territorium: reflexions sense resposta. Butlletí Arqueològic, èp. V: 32. A: LóPez, J., Martin, O. (ed.). Tarraco: construcció $i$ arquitectura d'una capital provincial romana. Actes del Congrés internacional en Homenatge a Theodor Hauschild. Volum II. Tarragona: 541-567.

Macias, J. M. (2014). El territorio y la ciudad de Tarraco. A: Pensabene, P., Sfameni, C. (a curi di). La villa restaurata e $i$ nuovi studi sull'edilizia residenziale tardoantica. Edipuglia. Bari: 453-465.

Macias, J. M., Menchon, J. J. (ed. científics) (2007). La vil.la romana dels Hospitals (el Morell, Tarragona). Un assentament de la via De Italia in Hispanias. Hic et nunc 1. Institut Català d'Arqueologia Clàssica. Tarragona.

Macias, J. M., Menchon, J. J., Puche, J. M., Remolà, J. A. (1997). Nous contextos ceràmics del segle IV i inicis del v en la província de Tarragona. Arqueomediterrània 2, Taula rodona Contextos ceràmics d'època romana tardana $i$ de l'alta edat mitjana (segles $I V-X$ ) (Badalona 1996). Barcelona: 153-178.

Macias, J. M., Morera, J., Olesti, O., Teixell, I. (2013). Crisi o invasió? Els Francs i la destrucció parcial de Tàrraco al s. III. A: Vidal, J., Antela, J. (ed.). Más allá de la batalla. La violencia contra la población en el Mundo Antiguo. Libros Pórtico. Saragossa: 193-214.

Macias, J. M., Remolà, J. A. (2000). Tarraco Visigoda: caracterización del Material cerámico del siglo VII dC. A: V Reunió d'arqueologia Cristiana Hispànica, Cartagena (1998). Barcelona: 485-498.

Malfitana, D. (2000). La ceramica corinzia a rilievo di età romana. Primi risultati di una ricerca in corso. Rei Cretariae Romanae Fautorum Acta, 36 (Abingdon): 181-188.

Marot, T. (1999). La moneda. La circulació monetària en l'època romana tardana (ss. III-V). La crisis del segle III en els dipòsits i en les troballes monetàries. A: Del Romà al Romànic. Història, Art i Cultura de la Tarraconense Mediterrània entre els segles IV $i \mathrm{X}$. Enciclopèdia Catalana. Barcelona: 329-339.

Marot, T., Ramon, E. (1999). Conjunt monetari de la vil.la dels Munts. A: Del romà al Romànic. Història, art $i$ cultura de la Tarraconense mediterrània entre els segles IV $i \mathrm{x}$. Enciclopèdia Catalana. Barcelona: 341.
Martin, A. (2012). Anàlisi tecnofuncional d'estructures productives vitivinícoles d'època romana. Identificació i localització a Catalunya de fosses de maniobra de premses de biga amb contrapès tipus arca lapidum: Pyrenae, 43, vol. 2 (2012): 53-98.

Martin, A., RodÀ, I., Velasco, C. (2007). Cella vinaria de Vallmora (Teià, Barcelona). Un modelo de explotación vitivinícola intensiva en la Layetania, Hispania Citerior (s. I a.C. - s. v d. C.). Hìstria Antiqua, 15: 195-212.

Martínez, J. (2003). Las estructuras antropológicas del imaginario órfico. El cetro, la crátera y el niño. Tesi doctoral inèdita. Universitat de Barcelona.

Mateu, F. (1950). El hallazgo de denarios romanos de Altafulla. Boletín Arqueológico, èp. IV, fasc. 30: 53-58.

Miró, B. (1991). La terra sigillata africana a Ilerda. Revista d'Arqueologia de Ponent, 1 (Universitat de Lleida): 223-237.

Navarro, R. (1979). Los mosaicos romanos de Tarragona. Tesi doctoral inèdita. Universitat de Barcelona.

Navarro, R. (1999). Mosaics romans a la vil.la de Paret Delgada. A: Del romà al Romànic. Història, art $i$ cultura de la Tarraconense mediterrània entre els segles IV $i$ X. Enciclopèdia Catalana. Barcelona: 133-134.

Nolla, J. M., Aquilué, X. (1984). Notes sobre una cassola de cuina de ceràmica africana procedent d'Empúries. Informació Arqueològica, 42 (Barcelona): 51-57.

Nolla, J. M., Nieto, F. J. (1979). Acerca de la cronología de la muralla romana tardía de Gerunda: la Terra Sigillata Clara de Casa Pastors. Faventia, 1/2 (Universitat Autònoma de Barcelona): 263-283.

Otiña, P. (2005). La vil.la romana dels Munts (Altafulla). Fundació Privada Liber. Reus.

Palet, J. M. (2005). Estructuras agrarias en el territorio de Tárraco (Tarragona): organización y dinámica del paisaje en época romana. A: Bouet, A., Verdin, F. (eds.). Territoires et paysages de l'âge du fer au moyen âge. Mélanges offerts à Philippe Leveau. Editions Ausonius. Bordeus: 213-226.

Palet, J. M. (2008). Formes del paisatge i trames centuriades al Camp de Tarragona: aproximació a l'estructuració del territori de Tarraco. A: Remolà, J. A. (coord.). El territori de Tarraco: vil.les romanes del Camp de Tarragona. Forum. Temes d'Història i d'Arqueologia Tarragonines 13. Museu Nacional Arqueològic de Tarragona. Tarragona: 49-64.

Paz Peralta, J. A. (2008). La producción de cerámica vidriada. A: Bernal, D., RiBera, A. (eds. científicos). Cerámicas hispanorromanas. Un estado de la cuestión, XXVI Congreso Internacional de la Asociación Rei Cretariae Romanae Fautores. Cadis: 489-494.

PiÑol, Ll.; LóPEZ, J. (2001). Complejos termales en las villae tardorromanas del Camp de Tarragona (Ager 
Tarraconensis). Arqueología y Territorio Medieval, 8: 77-96.

Ramón, E. (2008). La vil.la romana de la Llosa Vilar (Cambrils, Baix Camp). A: Remolà, J. A. (coord.). El territori de Tarraco: vil.les romanes del Camp de Tarragona. Forum. Temes d'Història i d'Arqueologia Tarragonines 13. Museu Nacional Arqueològic de Tarragona. Tarragona: 153-170.

Remolà, J. A. (2000a). Las ánforas tardo-antiguas en Tarraco (Hispania Tarraconensis). Instrumenta 7. Universitat de Barcelona. Barcelona.

Remolà, J. A. (2000b). La vil.la romana de Centcelles (Constantí, Tarragonès). A: Remolà, J. A. (coord.). El territori de Tarraco: vil.les romanes del Camp de Tarragona. Forum. Temes d'Història i d'Arqueologia Tarragonines 13. Museu Nacional Arqueològic de Tarragona. Tarragona: 171-189.

RemolÀ, J. A. (2003). Les vil.les romanes del Moro (Torredembarra). Butlletí Arqueològic, èp. V, 25 (Tarragona): 57-87.

Remolà, J. A., Pérez, M. (2013). Centcelles y el praetorium del comes Hispaniarum Asterio en Tarraco. Archivo Español de Arqueología, 86 (Madrid): 161-186.

Roca, M., Fernández, M. I. (coords) (1999). Terra sigillata hispànica. Centros de fabricación y producciones altoimperiales, Universidad de Jaén/Universidad de Málaga. Málaga.

Roig, J. F., Gimeno, M., Garcia, P. (en premsa). La vil.la romana dels Castellets (La Canonja, Tarragonès): un assentament romà de l'Ager Tarraconensis. Resultats preliminars de la intervenció arqueològica”. Tribuna d'Arqueologia. Departament de Cultura. Generalitat de Catalunya. Barcelona.

Romero, M. V., Ruiz, P. (2005). Los centros de producción de T.S.H. en la zona septentrional de la península Ibérica. A: Roca, M., Fernández, A. I. (coords.). Introducción al estudio de la cerámica romana. Una breve guía de referencia. CVDAS, revista de Arqueología e Historia. Universidad de Málaga: 185-223.

SANnAZARo, M. (2005). Ceramica invetriata. A: GANDOLFI, D. (a cura di). La ceramica e $i$ materiali di età romana. Classi, produzioni, commerci e consumi. Istituto Internazionale di Studi Liguri. Bordighera: 423-432.
Serra I Vilaró, J. (1950). Callipolis. Boletín Arqueológico, èp. IVa, 37-40 (1952): 13-19.

Serrano, E. (2005). Cerámicas Africanas. A: RocA, M., FeRnÁndez, A. I. (coords.). Introducción al estudio de la cerámica romana. Una breve guía de referencia. CVDAS, revista de Arqueología e Historia. Universidad de Málaga: 226-303.

SpITZER, D. C. (1942). Roman Relief Bowls from Corinth. Hesperia, XI (Princeton): 162-192.

Tarrats, F., Macias, J. M., Ramon, E., Remolà, J. A. (1998). Excavacions a l'àrea residencial de la vil.la romana dels Munts (Altafulla, Tarragona). Empúries, 51: $197-225$.

Tarrats, F., Macias, J. M., Ramon, E., Remolà, J. A. (2000). Nuevas actuaciones en el área residencial de la villa romana de 'Els Munts' (Altafulla, Ager Tarraconensis). Madrider Mitteilungen, 41: 358-379.

Tarrats, F., Ramon, E., Macias, J. M. (2000). Noves intervencions a la vil.la romana dels Munts (Altafulla, Tarragonès). Tribuna d'Arqueologia 1996-1997. Departament de Cultura. Generalitat de Catalunya. Barcelona: 36-56.

Tarrats, F., Remolà, J. A. (2000). La vil.la romana dels Munts (Altafulla, Tarragonès). A: Remolà, J. A. (coord.). El territori de Tarraco: vil.les romanes del Camp de Tarragona. Forum. Temes d'Història i d'Arqueologia Tarragonines 13. Museu Nacional Arqueològic de Tarragona. Tarragona: 95-117.

Tarrats, F., Remolà, J. A., Sánchez, J. (2008). La vil.la romana dels Munts (Altafulla, Tarragonès) i Tarraco. Tribuna d'Arqueologia 2006. Departament de Cultura. Generalitat de Catalunya. Barcelona: 213-228.

TeIXell, I. (2012). Nous contextos arqueològics relacionats amb l'entrada dels francs a Tàrraco en el segle III dC: la moneda com a element de datació post quem per a la recuperació de la ciutat. A: La moneda en temps de crisi. XVI Curs d'història monetària d'Hispània. Museu Nacional d'Art de Catalunya. Barcelona: 87-103.

Vegas, M. (1973). Cerámica común del Mediterráneo Occidental. Publicaciones Eventuales, 22. Universitat de Barcelona. Barcelona. 